Florida International University FIU Digital Commons

3-23-2009

\title{
May-SHEE-Ka from Atzlan for Large Orchestra and (SATB) Soprano, Alto, Tenor, and Bass Choir
}

Jaime Salvador Reveles

Florida International University, jaimereveles@gmail.com

DOI: $10.25148 /$ etd.FI10022543

Follow this and additional works at: https://digitalcommons.fiu.edu/etd

\section{Recommended Citation}

Reveles, Jaime Salvador, "May-SHEE-Ka from Atzlan for Large Orchestra and (SATB) Soprano, Alto, Tenor, and Bass Choir" (2009). FIU Electronic Theses and Dissertations. 212.

https://digitalcommons.fiu.edu/etd/212 


\section{FLORIDA INTERNATIONAL UNIVERSITY}

Miami, Florida

MAY-SHEE-KA FROM AZTLAN FOR LARGE ORCHESTRA AND (SATB) SOPRANO, ALTO, TENOR, AND BASS CHOIR

A thesis submitted in partial fulfillment of the requirements for the degree of MASTER OF MUSIC

by

Jaime S. Reveles

2009 
To: Acting Dean Brian Schriner

College of Architecture and the Arts

This thesis, written by Jaime S. Reveles, and entitled May-SHEE-Ka from Aztlan for Large Orchestra and (SATB) Soprano, Alto, Tenor, and Bass Choir, having been approved in respect to style and intellectual content, is referred to you for judgment.

We have read this thesis and recommend that it be approved.

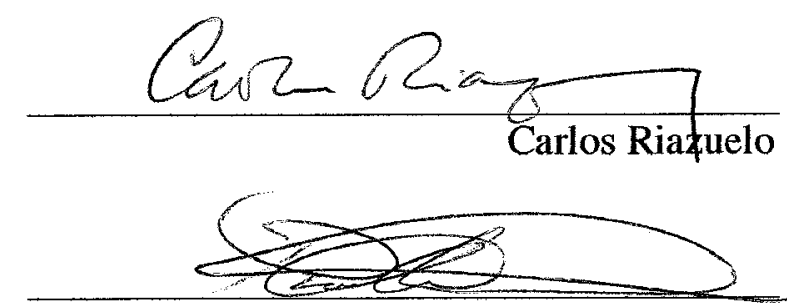

Paula Matthusen

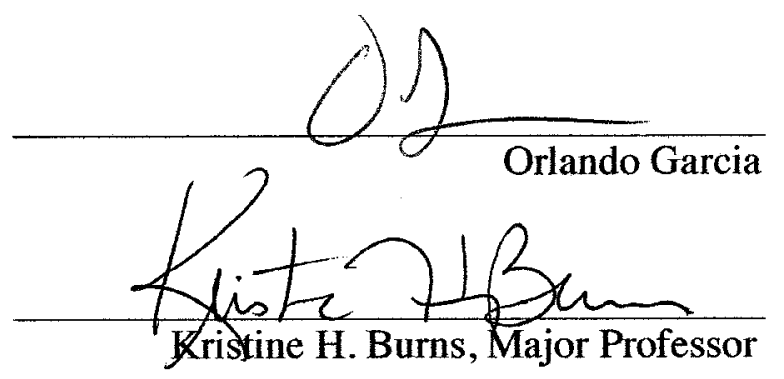

Date of Defense: March 23, 2009

The thesis of Jaime S. Reveles is approved.

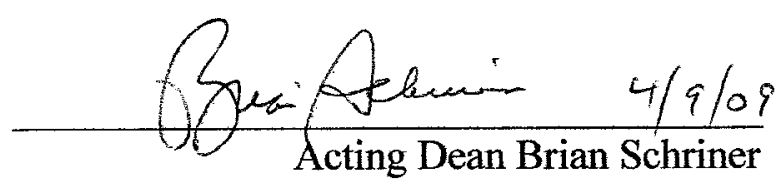

College of Architecture and the Arts

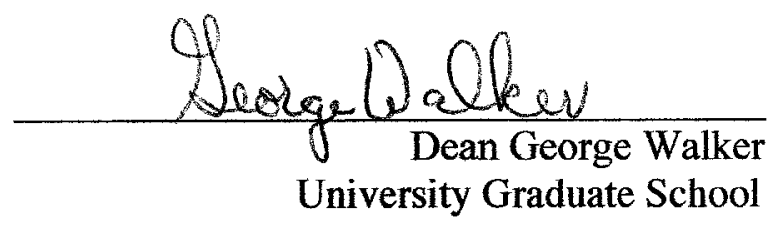

Florida International University, 2009 
(C) Copyright 2009 by Jaime S. Reveles

All rights reserved. 


\section{DEDICATION}

I dedicate this thesis to my wife Amelia. Without her patience, understanding, support, and most of all her unceasing love, the completion of this work would not have been possible. 


\section{ACKNOWLEDGMENTS}

I wish to thank my creator and Lord God for the opportunity, which he has always afforded me in my life; I have been blessed without measure. I dedicate this thesis to my beloved wife Amelia Lee Malone who has supported my dreams to pursue a higher education from the start; she has always encouraged me to dream big. I am also very grateful for all of the ceaseless prayers that my aunt Chaya Hinojosa has and still does petition to Lord in my behalf, I am indebted to her endless love and support for my pursuits. I would like to thank my mother Emma Reveles, who has been an ardent encouragement of my seeking out this degree, and she has been there for me when I needed her most, I am fortunate. I would like to also thank all of the members of my committee for their continued support, excellent advice, and for their great patience with me. Their direction has been very noteworthy in my accomplishments as a composer and the experience I have attained as an instructor, which is something I value enormously. There are many more persons who have contributed towards my success leading up to this placeholder in my life that I wish to thank, but because they are so vast in number I would fill these thirty plus pages with their names and their contributions alone. 


\begin{abstract}
OF THE THESIS
MAY-SHEE-KA FROM AZTLAN FOR LARGE ORCHESTRA AND (SATB) SOPRANO, ALTO, TENOR, AND BASS CHOIR
\end{abstract}

by

Jaime S. Reveles

Florida International University, 2009

Miami, Florida

Professor Kristine H. Burns, Major Professor

My composition May-SHEE-Ka from Atzlan for orchestra and choir creates a sound world that imagines what some of the sounds might have been like when the Mexica people first arrived on the banks of Lake Texcoco in the early development of the Mesoamerican region. This along with my research of the Mexicas musical and cultural practices provides the context for this work for full orchestra and SATB choir. The title of my work May-SHEE-Ka from Aztlan is derived from the pronunciation of the word Mexica in the Nahuatl language of Mesoamerica. Mexica is the name of the nomadic tribe more commonly referred to as the Aztecs. It is believed that the Mexica came from Atzlan, which is said to be the ancestral home of the Nahua peoples, a key cultural group of Mesoamerica. The word Azteca comes from the Nahuatl word for people from Atzlan. The title of this work is my own extraction of this historical understanding. 


\section{TABLE OF CONTENTS}

CHAPTER

PAGE

I. INTRODUCTION

THOUGHTS AND INSPIRATIONS FOR THE COMPOSITION ..... 1

II. HISTORICAL BACKGROUND

MEXICAN MYTHOLOGY AND THE MEXICAN PEOPLES ........ 7

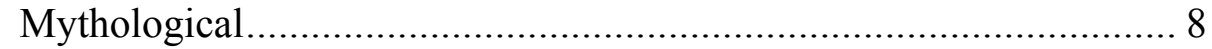

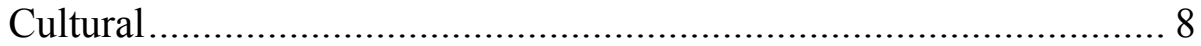

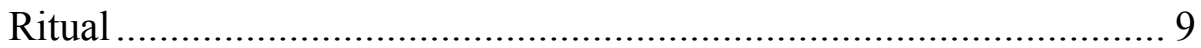

Music .............................................................................. 11

Organization of the Musical Material ........................................ 12

III. OVERVIEW, STRUCTURE AND TEXTURE ............................ 16

IV. ORCHESTRATION TECHNIQUES ...................................... 24

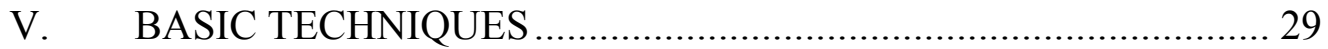

VI. VERTICAL MODELS....................................................... 31

VII. HORIZONTAL MODELS ...................................................... 40

VIII. STYLE ............................................................................ 47

IX. CESSATION CODA …................................................... 48

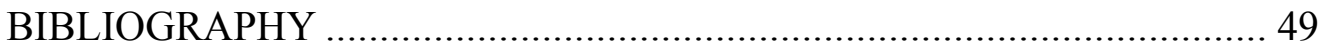

APPENDICES .............................................................................. 52 


\section{LIST OF FIGURES}

FIGURE

PAGE

1.1. Image of the Aztecs' concept of their Universe.

1.2. An illustration of segment ordering of May-SHEE-Ka from Aztlan

as it relates to the Aztecs concept of their Universe

2.1. Example of a rhythmic imitation from May-SHEE-Ka from Aztlan ....................... 19

2.2. Example of additive process hocket from May-SHEE-Ka from Aztlan

2.3. Example of a climactic polyrhythmic structure from

May-SHEE-Ka from Aztlan

3.1. Examples of ghost and whistle tone multiphonics, jet whistles, and multiphonic

tremolos in the piccolo, flute, and English horn

3.2. Examples of teeth on reed, singing with instrument, and split tongue techniques in the clarinet, bass clarinet, and French horn .........................................................2 25

3.3. An example the opening combination of the MP, and MS scales

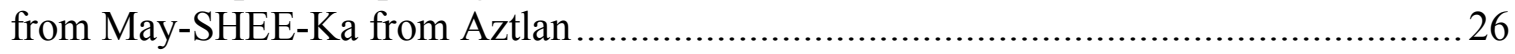

4.1. Example of pitch organization and rhythmic detail from

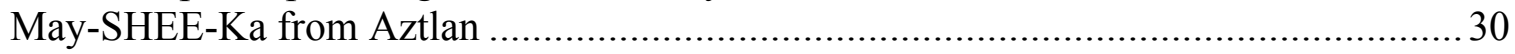

5.1. Berio's polyrhythmic orchestration from Formazioni........................................ 32

5.2. A harmonic rhythmic structure from May-SHEE-Ka from Aztlan.......................... 33

5.3 Berio’s Sinfonia: For Eight Voices and Orchestra movement II O King.................. 35

5.4a. Helmut Lachenmann's Ausklang: Musik für Klavier mit Orcheste ....................... 37

5.4b. Sostenuto pedaling from Lachenmann's Ausklang:

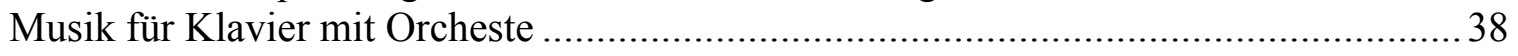

5.5. An illustration of the sostenuto pedaling from May-SHEE-Ka from Aztlan ............ 39

6.1. Schoenberg's use of Klangfarbenmelodie from

Five Pieces for Orchestra, op. 16 movement I Vorgefühle

6.2. Schoenberg's use of Klangfarben from Five Pieces for Orchestra,

Op. 16. Movement III Farben... 
6.3. Moving chords of color in brass in movement

III Farben from Schoenberg's Five Pieces for Orchestra, op. 16................................... 42

6.4. Moving chords of color to woodwinds in movement

III Farben from Schoenberg's Five Pieces for Orchestra, op. 16 ................................... 43

6.5. An example of tone-coloring from May-SHEE-Ka from Aztlan................................4 44

6.6. An example of Klangfarbenmelodie from May-SHEE-Ka from Aztlan.................... 46 


\section{INTRODUCTION}

\section{THOUGHTS AND INSPIRATIONS FOR THE COMPOSITION}

As a Mexican-American who has "Mexican-Indian" blood on my mother's side, and ancestral lineage from Jerez, Zacatecas, Mexico on my father's side, I feel a strong connection to the indigenous peoples of Mesoamerica. The more I understand their beliefs and musical practices, the more it evokes images and ideas of what life might have been like for the early Mexica arriving onto the lower banks of Lake Texcoco, which was located in what is now called the Valley of Mexico. The imagery elicited from researching what is known of these fascinating people in particular their complex lives, customs, and beliefs, guided me in creating an orchestral composition rich in sonorities with multiple sound dimensions. The Mexica left numerous artifacts and monuments behind of their civilizations; evidence of the music performed by Aztec musicians has lead to this understanding. Professor of Music at San Diego State University, Jack Logan, from his research of the music of Latin America states:

From the structure of ancient instruments which have been preserved: "(1) Flutes, Chililihtli; and ocarinas and panpipes, Tlapitzalli; (2) Marine snail shell, Atecocoli; (3) Vertical drum, Huehuetl; (4) Horizontal drum, Teponaxtle; (5) Calabash rasps, Tzicahuaztli; and bone rasps, Omichitzicahuaztli; (6) Gourd filled with pebbles, Ayacaztli,"7 the observation is made that the music of the ancient Mexican civilizations was predominantly pentatonic in nature with the minor third at the base of the scale as follows: la, do, re, me, sol. ${ }^{1}$

\footnotetext{
${ }^{1}$ Jack Logan Professor of Music San Diego State Music of Latin America: Music in Our World Parts and References website. http://trumpet.sdsu.edu/m151/Music_of_Latin_America1.html (Accessed September 30, 2008).
} 
This pattern of the pentatonic scale is implemented in my composition to relate to the Mexica people. A percussive repetition along with a ritual drone provides a passing reference to their historic ritual practices. I utilize my own text written in the Nahuatl language in combination with a poem written by an Aztec Lord that I fragment to create my written material for the chorus. The sounds of the Mexicas native instruments (namely their drums, flutes, trumpets, and ocarinas) influenced my timbral choices regarding instrumentation and how the musical material is orchestrated. Structurally, numerology based on the Aztec calendar is employed to develop the structure in my orchestral work; this will be detailed later in the paper.

When I began to research orchestral music influenced or associated with the Aztecs, the one name that kept coming up was Carlos Chávez. Chávez was a Mexican conductor and composer who combined elements of traditional folk songs and occasionally used native Mexican instruments along with modern compositional techniques. His orchestral composition Sinfonia India (Symphony No. 2) is the most famous work of his that includes the use of native Yaqui percussion instruments. This piece was one of the first pieces that I look to as a reference, but it was not the one that stood out for me. Instead I was intrigued with Chávez’s Xochipili-Macuilxochitl (named for the Mexican god of music). The problem was finding a score, and a recording of a performance for me to analyze and hear. What really fascinated me about this Chávez piece was how a journalist from Time Magazine described an event where the piece was performed. The article described its background connection to the Mesoamerican Indians and their ancient music. An online article dated "Monday, May. 27, 1940," in the introductory paragraph read: 
Thousands of years ago, somewhere on the warm seacoasts of the North American continent, an Indian picked up a sea snail's shell, blew a tentative toot. He had a horn. Perhaps he did not catch on at once, but his horn was tuned naturally to a pentatonic (five-note) scale. The Indian and his friends contrived other instruments to thump and tootle with the snail's shell. By the time the Aztec civilization was at its height, and the Spaniards arrived in Mexico, the Indians were playing teponaxtles (wooden cylinders, with tongues inside producing two different notes), huehuetls (tree-trunk drums), pipes and flutes of clay, rattles and rasps of many materials. All the Aztec instruments of definite pitch were tuned to the five-note sea shell's scale. As early Spanish chroniclers noted, the Aztecs played and sang ballads, war songs, dance rituals. But no one ever wrote down a note of their music. ${ }^{2}$

The author here was qualifying Chávez's composition Xochipili-Macuilxochitl for orchestra, as it had just been performed in Manhattan New York, as part of a show that was exhibiting Mexican art at the Museum of Modern Art. In the end I relied on my own imagined sound world, and developed my approaches based on the research of the lives and practices of the Mexica to influence techniques used in my composition May-SHEEKa from Aztlan. These various techniques all serve to invoke a notion of what I imagine a day in their lives might have sounded like with all of its cultural significance. Through the use of extended techniques in many of instruments of the orchestra I combine my own aesthetic and musical language with my imagined sound world of the Mexica. I will be reviewing some of the forms employed in analyzing music compositions, and how they relate to my decision to use David Cope's method termed vectoral analysis described in his book New Directions in Music. ${ }^{3}$

By understanding how a particular work is structured one can begin to understand the elements that make up a piece. This is needed to help the analyst visualize what the

\footnotetext{
2 Time Magazine. "Aztec music." (In Time Magazine Online, Time Inc. http:/www.time.com/time/magazine/article/0,9171,884120,00.html) (Accessed August 13, 2008).

${ }^{3}$ David Cope, New Directions in Music. (Long Grove, IL: Waveland Press Inc., 2001) v - vi.
} 
composer's intentions might have been when it was first conceived. Some of the most interesting music compositions are very complex, but understanding how this music is structured helps to break down the walls of complexity, and expose the process of the work. Most all music contains an underlying structure, and Western art music evolved from various standardized structures of musical form that define the hierarchy of its musical components. A piece of contemporary music will traditionally be made up of extended complex forms that are not so easily recognizable by the untrained ear.

These forms have are broken down into individual systems of organizing musical material. This classification of the musical components may help bring to light what the composers intentions were when composing the piece. For example pitch material could be developed throughout the various orchestral instruments, over an established timeframe, and through the classification of these pitches one can analyze what the composer may have intended when composing. The approach that one takes when analyzing a composition may assist in revealing how the composer created the work. While these approaches vary in their usefulness, this is a polemic issue that will not be addressed here.

Conventionally, tonal music is examined and categorized by chord analysis where the music is divided up harmonically to identify the chord progression of a piece. This can be helpful if the composition is based on a Western musical approach to tonality that can be analyzed through figured bass Roman numeral analysis.

Another way to analyze tonal music is through Schenkerian analysis. This approach to analysis describes large-scale structures in a composition by looking at hierarchical pitch relationships. The music is reduced to its simplest skeletal shape 
through the use of Schenker's own specialized symbolic form of musical notation, based on descriptions of prolongation, which pushed the Roman numeral analysis in a new direction. ${ }^{4}$ Schenkerian analysis uncovers tonality in music by revealing -"underlying" -structures. Felix Salzer calls this "Structural Hearing," which is described in his book Structural Hearing: Tonal Coherence in Music. Salzer claims that much of this approach to analysis has yet to be explored, and it may serve to "contribute towards establishing a truly modern style of composition." 5 For analysis of atonal compositions, and more experimental works another analytical option is "vectoral analysis."

Developed by composer David Cope, vectoral analysis provides a macro approach to analysis that presents a seven-step method to address more contemporary experimental music. ${ }^{6}$ This process unfolds linearly beginning with the historical background of the composition. This first step includes the time period of the composition, historical influences that brought about its creation, and important influential teachers of the composer. In the process of the second step labeled "overview" one examines the composition from a general summary perspective that looks at structure, and texture. Here the overall structure of the composition, rhythmic concepts, and any specific compositional techniques that are examined. The process of the third step labeled "orchestration techniques" the timbre, instrumentation, unusual techniques, instrumental range, and the relationship of timbre to form are, analyzed. The fourth step labeled "basic techniques" includes a discussion of pitch material, motivic

\footnotetext{
${ }^{4}$ Felix Salzer, Structural Hearing: Tonal Coherence in Music. (New York; Dover Publications,

${ }^{5}$ Felix Salzer, Structural Hearing: Tonal Coherence in Music, xvii.

${ }^{6}$ David Cope, New Directions in Music. v - vi.
} 1982), $10-14$. 
structure, and rhythm. In the fifth step labeled "vertical models" one analyzes harmonic structure. In the sixth step labeled "horizontal models" one examines melodic structures as they relate to cadences, motion and balance. The seventh and last step labeled "style" one looks at an overview of "stylistic parameters" and other formal, melodic, and harmonic techniques. ${ }^{7}$ Vectoral analysis is ideal for understanding how I compiled material for May-SHEE-Ka from Aztlan. Cope's approach was the best suited to analyze my composition May-SHEE-Ka from Aztlan, because of the way that he divides his approach into seven stages that I felt would help extract the salient musical elements that make up my composition.

${ }^{7}$ David Cope, New Directions in Music, v-vi. 


\section{HISTORICAL BACKGROUND}

\section{MEXICAN MYTHOLOGY AND THE MEXICAN PEOPLES}

The purpose of giving an overview of the lives and practices of the Mexica peoples is to establish a vivid picture of my inspiration for this orchestral work. As one begins to get a glimpse of the lives and practices of the Mexica from their daily life, art, beliefs and especially their musical practices with regard to ritual, one can better understand my motivation for this work. I set out to create a sound world that infuses these sensibilities along with my own approach and aesthetic to composition.

Many of the Mesoamerican tribes that preceded the Mexica and their settlements had small and large ceremonial centers with ritual spaces. In these spaces, religion, common worldviews, and mythology were shared and expressed through ritual performances, paintings, sculptures, and architecture. ${ }^{8}$ Though much has yet to be revealed about the Aztecs, it is undeniable that the Aztec Empire left a monumental impression on the histories of civilizations. As mentioned before the term, "Aztec" in Nahuatl means "people of Aztlan." This name was coined after the Conquest. ${ }^{9}$ In referring to the Mexica in this research study both terms will be used interchangeably. What follows is and exploration of their mythology, cultural, ritual, and musical background and beliefs.

${ }^{8}$ David Carrasco, and Scott Sessions, Daily Life of the Aztecs: People of the Sun and Earth. (Indianapolis: Hackett Pub. Co, 2008), $25-26$.

${ }^{9}$ N. James, Aztecs \& Maya: The Ancient Peoples of Middle America. (Stroud, Gloucestershire: Tempus, 2001), 107. 


\section{Mythological}

The Aztecs looked at themselves as "people of the sun and earth," they were politically organized and intimidating. They traded and had warfare with hundreds of towns and communities who "paid rich tributes to the royal families and markets of the capital" Tenochtitlan. ${ }^{10}$ The Aztecs looked at this capital as their place of origin, and Tenochtitlan was founded in their Fifth Sun era, which in their belief was "created in a sacrificial fire at the beginning of time.",11

\section{Cultural}

Aztecs transmitted their culture, history, and traditions as well as their calendars through pictorial manuscripts, which were painted cosmologies, and histories. These manuscripts told stories and described the complexity of the Aztecs lives; they were painted on animal skins, and on the surface of tree bark. Their ritual formulas of Aztec daily life and "vital indigenous world views" illuminated these documents. ${ }^{12}$ These images conveyed "literal" and "metaphoric" messages about all facets of life. In a "pictograph" the images represented those persons, places, and things themselves, and in "ideographs" image symbols of objects represented ideas related or associated with the image. One example of this would be an image of a flower, which would either represent a literal flower, or in an ideograph the image of a flower could mean sacrificial blood or a poem. ${ }^{13}$ Although 16 still remain today many of these valuable pictographs no longer exist because in 1535

\footnotetext{
${ }^{10}$ David Carrasco, and Scott Sessions, Daily Life of the Aztecs, xi-xii.

11 David Carrasco, and Scott Sessions, Daily Life of the Aztecs, $31-2$.

12 David Carrasco, and Scott Sessions, Daily Life of the Aztecs, 13 - 15.

13 David Carrasco, and Scott Sessions, Daily Life of the Aztecs, 15.
} 
Spanish Bishop Juan de Zumárraga (1468 - 1548) confiscated and destroyed hundreds of them. Along with these are various other accounts from the descendants of Aztecs, Europeans and mestizos (persons of mixed Indian and European ancestry). One of which is the "Florentine Codex," created by a Spanish priest named Bernardino de Sahagún (1499 - 1590) who assembled this document throughout the heart of the 16th century. ${ }^{14}$

\section{Ritual}

Sahagún a simple and devoted Franciscan friar, methodically gathered and documented accounts of the lives of the Aztecs in his illustrated and partially autographed manuscript labeled Historia general de las cosas de Nueva España. ${ }^{15}$ This 12-volume encyclopedia, which took Sahagún, along with the help of knowledgeable native assistants approximately 30 years to compile, is a narrative of the lives of the Meso-American peoples. ${ }^{16}$

The documented practices of the Aztecs, reveals both that they were an exceptionally religious society and that their religion was very complex and demanding. The Aztecs were extremely superstitious and believed that at night demons came out and lurked around terrifying those "unwise enough to venture out."17 Their gods were enduringly threatening, and angry because their primary god was Huitzilopochtli the Sun. In order to keep the sun rising everyday, the Aztecs had to appease Huitzilopochtli with

14 David Carrasco, and Scott Sessions, Daily Life of the Aztecs, 14 - 15.

15 Franca Arduini, The World of the Aztecs, in the Florentine Codex. The library on display, 1. (Florence: Mandragora, 2007), 5 -6.

${ }^{16}$ Franca Arduini, The World of the Aztecs, in the Florentine Codex, 7 -9.

${ }^{17}$ Brenda Ralph Lewis, The Aztecs. Sutton Pocket Histories. (Stroud: Sutton Pub, 1999), 50. 
human blood from sacrificed captives. ${ }^{18}$ They believed that the gods had originally sacrificed themselves to create the world and human hearts and blood from sacrifices repaid this debt. The Mexica also believed that the Sun was in its fifth cycle of recreation, and that the end of the world was not random, but would arrive at the end of one of their 52-year cycles. The Aztec calendar was an important part of everyday life and ritual, which brings to light the utmost importance of how the Aztecs organized their existence with numerical consistency. Brenda R. Lewis defines this clearly by stating:

The careful reckoning of the Aztecs Calendar, which included the vital 52year cycle, lay at the heart of priestly activities. Here, a multiple and several factors of the number 52 recurred, with 13 as a sacred number; the ritual calendar consisted of 260 days. There was a cycle of thirteen numbers, which ran in harness with another cycle, of twenty days. The groups were controlled by thirteen gods known as Lords of the Day as well as by thirteen sacred birds and nine Lords of the Night. ${ }^{19}$

The Aztec calendar organization gave special emphasis to the number 13 - a number especially sacred and special to them. In my composition I use the Aztec calendar to derive some of the numerical divisions of the thematic material. I took the date that I conceived this work, (July 7, 2008), and I entered this number into the online Aztec Calendar calculator, (http://www.azteccalendar.com). The corresponding Aztec date provides several different categories that are connected to this given day.

In my case the date July 7, 2008 supplies me with the following categories, Xihuit-solar year, is 9-Tecpatl and Yoaltecuhtli lord of the night, Itztli; Trecena: 13-day period is 1- Malinalli and Xiuhpohualli 365-day calendar, 14 Tepeilhuitl (XIV); and Tonalli: day, is 1 Malinalli. I divide sections of my composition by using the numerical

\footnotetext{
${ }^{18}$ Brenda Ralph Lewis, The Aztecs. Sutton Pocket Histories, 57 - 8.

${ }^{19}$ Brenda Ralph Lewis, The Aztecs. Sutton Pocket Histories, 58 - 60.
} 
values derived here. I will discuss the representation of each of these categories in my composition later in this paper.

\section{Music}

Prior to the conquest of the Mexica (Aztec) peoples of Mesoamerica, music was for ritual and religious practice only, and only a selected few controlled who performed music for their rituals and ceremonies. These same "professionalized caste members" also trained the singers and players to perform flawless performances. If a performer made a mistake by missing a beat, for example the punishment was severe, sentencing the performer to death. For the Aztec music was not considered an individualistic expression, but instead a communal one. ${ }^{20}$ Dance and music were customarily always together as was singing and instrumental performance.

The teponaztli, a slit-drum with two tongues played with mallets, and the huéhuetl, a single-headed drum open at the bottom, played with bare hands were the most sacred instrument for the Aztecs. Both instruments were considered the embodiment of gods. Particular instruments were also thought to hold supernatural powers and symbolically denoted delight, sensual pleasure and joy. ${ }^{21}$ Aztecs musicians tuned their various idiophones, aerophones, and membranophones with great care as they had a keen sense of pitch. From the article on Aztec music in the Grove Music Online, Robert Stevenson and Arturo Chamorro outline some very specific quality and attributes to Aztec music stating:

${ }^{20}$ Robert Stevenson, and Arturo Chamorro. "Aztec music." (In Grove Music Online. Oxford Music Online, http://www.oxfordmusiconline.com/subscriber/article/grove/music/01636) (Accessed September 30, 2008).

${ }^{21}$ Robert Stevenson, and Arturo Chamorro. "Aztec music, " In Grove Music Online. (Accessed September 30, 2008). 
Every piece of music was composed for a certain time, place and occasion, so that a musician needed a wide repertory if he was to satisfy the demands of the different days in the 260-day religious calendar...Bold, assertive qualities such as loudness, clarity and high pitch were preferred by players and singers alike. ${ }^{22}$

The Mexica (Aztecs), like their ancestors the Chichimecs and Toltecs, were fascinated with bilateral symmetry, which is highlighted in the mirror images of the sculptures of their gods, and the symmetry to their architecture. This idea was connected to the understanding that their world was the creation of the gods, who combined all things as their artwork, and the task of all humans was to form art and the world to imitate what the gods had originally created "art and architecture were viewed as imitations of cosmological patterns and truth". ${ }^{23}$

\section{Organization of the Musical Material}

In establishing the sound world for May-SHEE-Ka from Aztlan, I chose to use two scales. I utilize a pentatonic scale in a sequence of pitches, which relates to what was utilized with the Mexicas first wind instruments — a conch shell. I spell this (Mexica pentatonic) scale $\mathrm{Gb}, \mathrm{Ab}, \mathrm{B}, \mathrm{Db}, \mathrm{Eb}$. This scale represents the more whimsical side of the Mexica peoples, the lighter aspect of their everyday lives. This scale itself was not the actual one used by the Mexica, but instead is one that I created to represent this. From the more elite royal members to the poorer lower classes of their culture, all seemed to have a variety of small anklets and bracelets with tiny bells attached to them some of clay others of gold and silver. They were also found on the sandals of lords and princes. This

\footnotetext{
${ }^{22}$ Robert Stevenson, and Arturo Chamorro. "Aztec music, " In Grove Music Online. (Accessed September 30, 2008).

${ }^{23}$ David Carrasco, and Scott Sessions, Daily Life of the Aztecs, 160 - 1.
} 
indigenous aspect of the Aztecs continually produced "bell-toned" sounds, which I consider whimsical. $^{24}$

The second scale I use in this work is a synthetic scale I created experimenting at the piano with pitches that I felt symbolized a more mystical and perhaps darker side of what I imagined could be associate with the Mexica peoples. I refer to this as the Mexica scale (May-SHEE-Ka). This synthetic scale features two triads a half-tone apart consisting of the pitches F\#, G, A, Bb, D, Eb. The first triad is built on a minor second and major second, which is the dissonant component of the scale. The second triad is built on a major third and a minor second, which represents the consonant component of the scale, although I break this orientation apart and rearrange the pitches in various ways.

The composition is divided into five sections I refer to as segments with a prelude consisting of eight measures. The first section acts as a prelude to the piece, and the remaining five sections, or segments relate to the Aztec belief that their world existed under a fifth sun. ${ }^{25}$ The Aztecs divided their world into five major sections; four quarters of their universe were represented as trapezoids, which were organized around a central square fifth section or space (see Figure 1.1.). In the center square contained an armed warrior with torrents of blood flowing into the four trapezoids, which represented the four-quarters of their universe. ${ }^{26}$

${ }^{24}$ Frederick H. Martens, "Music in the Life of the Aztecs,” The Musical Quarterly, Vol. 14, No. 3 (Jul., 1928), Oxford University Press, Stable URL: http://www.jstor.org/stable/738439, (Accessed: 30/09/2008 17:33), 432 .

25 David Carrasco, and Scott Sessions, Daily Life of the Aztecs: People of the Sun and Earth. (Indianapolis: Hackett Pub. Co, 2008), 37-41.

${ }^{26}$ David Carrasco, and Scott Sessions, Daily Life of the Aztecs, 45-46. 


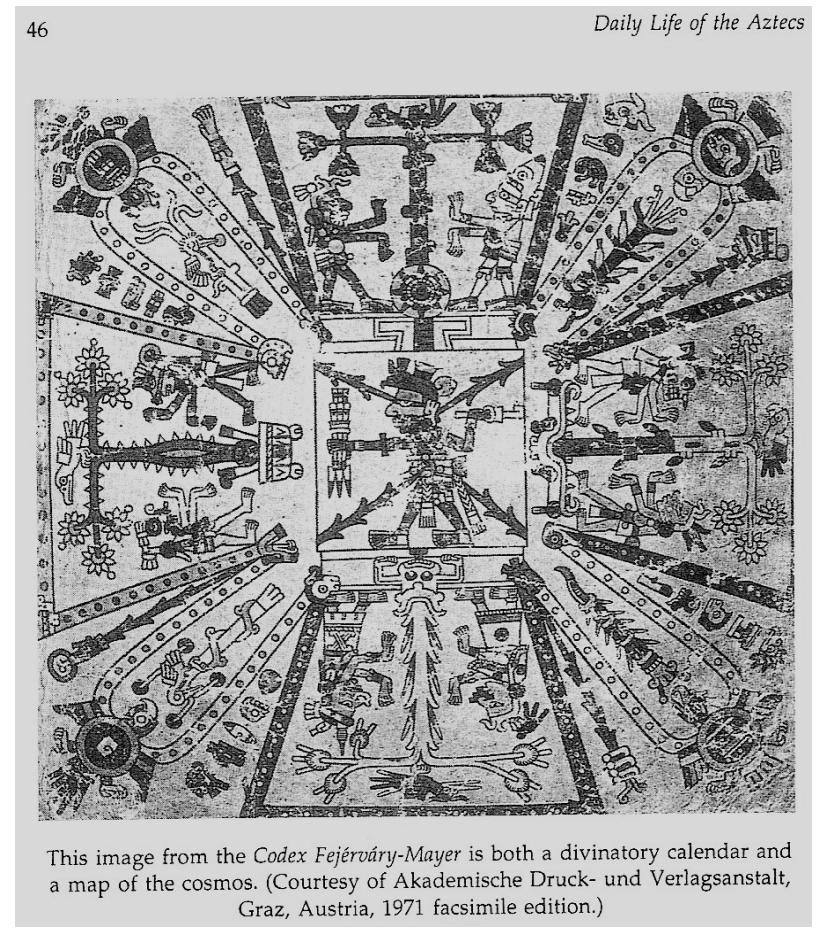

Figure 1.1. Image of the Aztecs concept of their Universe

I use this concept of the Aztec's method of dividing their universe as a way to organize my piece. The first three segments represent three of the trapezoids leading to segment IV, which I associate with this "center space.” Segment V represents the fourth trapezoid of Aztecs concept of the universe. An example of this configuration is provided in Figure 1.2. 


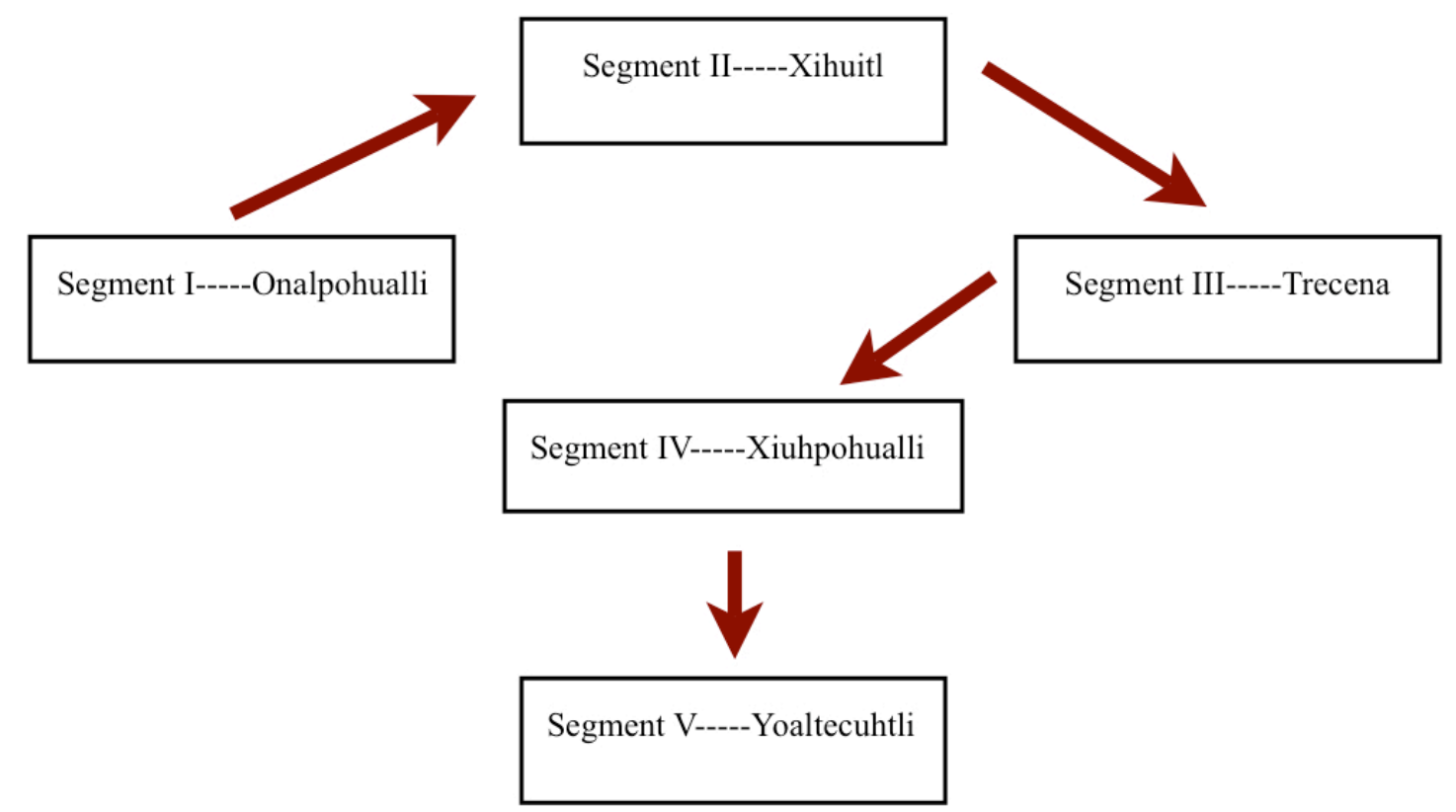

Figure 1.2. An illustration of segment ordering of May-SHEE-Ka from Aztlan, as it relates to the Aztecs concept of their Universe

The five-segments including a prelude that make up this composition, are labeled as follows:

1. Prelude----------------------Itztli (god of stone and sacrifice) measures 1 - 8

2. Segment I----------------- Onalpohualli (count of days) measures 9 - 32

3. Segment II-----------------Xihuitl (solar year); 9----Tecpatl (flint knife) measures 33 - 56

4. Segment III-----------------Trecena (13-day period); 1----Malinalli (grass) measures 57 104

5. Segment IV--------------- Xiuhpohualli (365-day calendar); 14--------Tepeilhuitl (feast of the mountain) measures $105-178$

6. Segment V------------------Yoaltecuhtli (Lord of the Night) measures 179 - 207 


\title{
III. OVERVIEW, STRUCTURE AND TEXTURE
}

\begin{abstract}
"Nothing preestablished bars the composer from the sound that he needs here, and only here. Nothing preestablished compels him to submit to the traditionally universal. The possibility of technical control of the material developed together with its emancipation. It is as if music had wrested itself free of any purported natural constraint imposed by its matter and was able to dispose over it freely, consciously, and lucidly. The composer emancipated himself along with the sounds." Theodor W. Adorno, Philosophy ${ }^{27}$
\end{abstract}

Adorno is speaking here about the natural tendency of composers to do in music what they need to do. When I compose music I don't think of the rules of music or composition and then pour my ideas into a mold to produce a piece, but instead pursue an approach that will help me realize what I imagine in my mind. I apply little to no restricting principles on myself; this is why I chose not to write tonal music with its restricted number of combinations for solving resolutions vertically. Music for me is inspiration to create more music, whether a solo clarinet piece, a small chamber piece including electronics, an acoustic piece for strings and piano, or a large-scale orchestral work like May-SHEE-Ka from Aztlan. I look to the works of various composers by examining a number of their works to draw inspiration, in particular those whom I wish to emulate. This list of composers is indeed long, but I will name just the few that I immersed myself in when beginning this venture. Arnold Schoenberg's Five Pieces for Orchestra, op. 16, movements I Vorgefühle, and III Farben, ${ }^{28}$ Anton Webern's Symphony, Op. 21, ${ }^{29}$ and Six Pieces, Op. $6,{ }^{30}$ Luciano Berio's Formazioni, ${ }^{31}$ and

27 Theodor W. Adorno, and Robert Hullot-Kentor. Philosophy of new music. (Minneapolis: University of Minnesota Press, 2006), 44.

${ }^{28}$ Arnold Schoenberg, Fünf Orchesterstücke: Originalfassung, Five pieces for orchestra: original version, op. 16. (London: Eulenburg, 1950).

${ }^{29}$ Anton Webern, Symphonie, für Klarinette, Bassklarinette, 2 Hörner, Harfe, 1. und 2. Geige, Bratsche, und Violoncell, op. 21. (Wien: Universal Edition, 1929)

${ }^{30}$ Anton Webern, Sechs Stück-e —Six Pieces: Op.6. (Wien: Universal, 1928). 
Sinfonia, ${ }^{32}$ Pierre Boulez's Notations: Pour Orchestre, ${ }^{33}$ Helmut Lachenmann's Ausklang: Musik für Klavier mit Orcheste, ${ }^{34}$ and Tableau: Für Orchester, ${ }^{35}$ Toru Takemitsu's orchestral work Riverrun: for Piano and Orchestra, ${ }^{36}$ and November Steps, ${ }^{37}$ Edgard Varèse's Arcana,${ }^{38}$ Salvatore Sciarrino's Aspern-Suite: Per Soprano e Strumenti, ${ }^{39}$ Krzysztof Penderecki's Passion according to St. Luke, ${ }^{40}$ and George Crumb's Variazioni ${ }^{41}$ and $A$ Haunted Landscape, ${ }^{42}$ were works I focused on and listened to for inspiration.

I was attracted to their approaches to composition for a starting point from which to venture into my composition May-SHEE-Ka from Aztlan. Although the orchestra's size and scope has changed much over the past centuries it remains a good place to experiment with the various timbres of sound and texture coming from many of the instruments of the orchestra. As I considered composing a piece for my master's thesis I

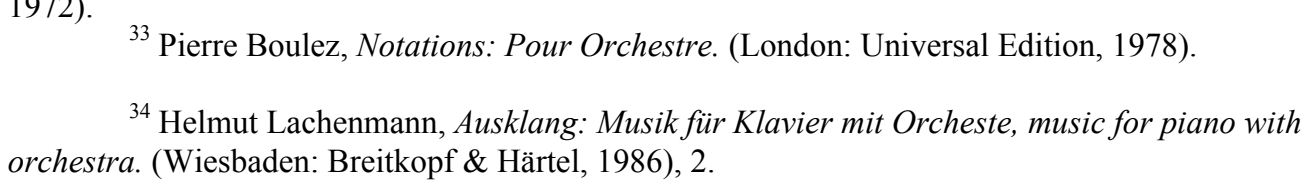
orchestra. (Wiesbaden: Breitkopf \& Härtel, 1986), 2. Härtel, 1989).

${ }^{35}$ Helmut Lachenmann, Tableau: Für Orchester (For Orchestra). (Wiesbaden: Breitkopf \&

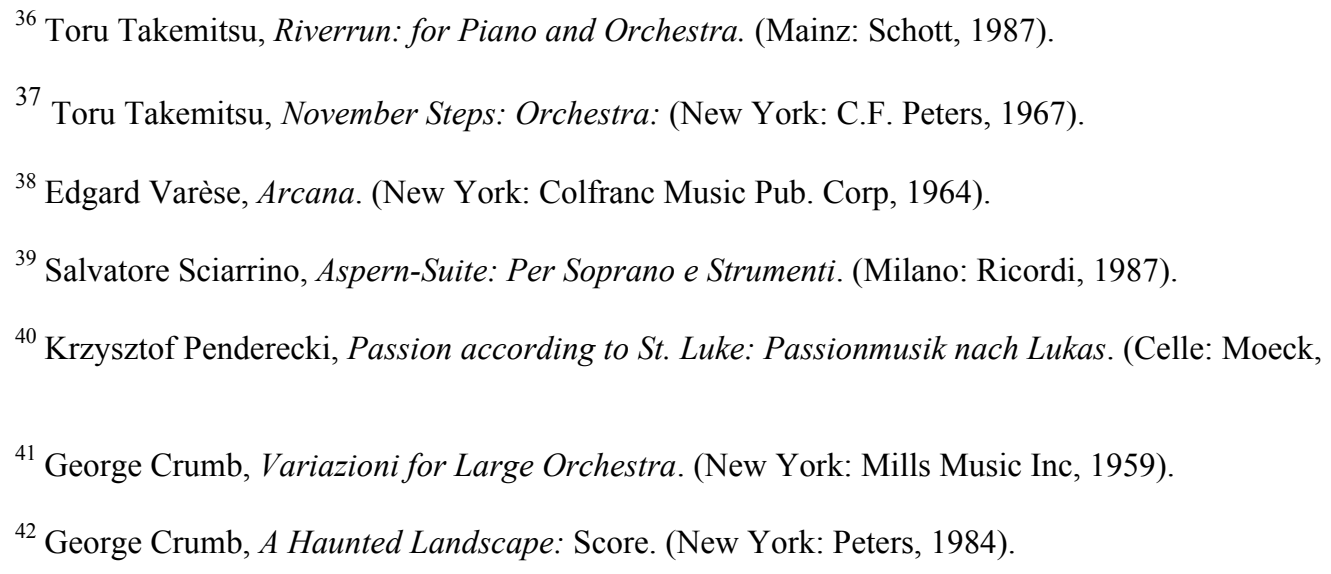


looked at the works of the aforementioned composers for ideas on how to expand my knowledge and experience at composing for orchestra. These composers explored areas of writing for orchestra that interested me for my composition. Because their works looked at new timbres, textures and techniques, which where groundbreaking in their time, it stimulated my creativity.

From this research I began to imagine a sound world that consisted of primitive instruments like the conch shell, various hand made idiophones, and the Aztec's two known sacred drums, the teponaztli, and the huéhuetl. I did not want to necessarily use these instruments in my work, but instead focus on a similar sound world to evoke an emotional response related to them. Since their music was primarily percussive, I imagined large clusters of polyrhythmic textures sounding simultaneously. Aztec music inhabited their everyday world, where music existed in rhythmic structures driven by ritual ceremony and intense focus, and their music required extreme attention to untarnished performances. ${ }^{43}$ With this in mind I interpreted what I associated with the lives and musical practices of the Mexica, along with how I imagined it might have sounded. My work for orchestra is associated with these elements, and I created a work that is inspired by the images of primitive rhythmic pulses and ritual musical practices that included singing.

The approximate duration of May-SHEE-Ka from Aztlan is 19 minutes; the composition is divided into five segments with a short eight-measure prelude. This piece is an atonal work that is not programmatic in nature. Rather it is through composed with many sections of imitation and variation, where short fragments are repeated and

${ }^{43}$ Robert Stevenson, and Arturo Chamorro. "Aztec music." (In Grove Music Online. Oxford Music Online, http://www.oxfordmusiconline.com/subscriber/article/grove/music/01636) (accessed September 30, 2008). 
developed. Instrumental families of instruments are divided into bilateral symmetry, where I pair them in symmetry intuitively. I dived pitches bilaterally between instruments and instrument families to create my own unique form of symmetry. For example in $\mathrm{m} .46$ in the choir I have the soprano and bass singers doubling pitch D and $\mathrm{G}$, while the alto and tenor singers double on pitch A. Counterpoint is used throughout the composition, and more pronounced through the sections of rhythmic imitation as in mm. $17-30,75-89$, and $191-202$. One example of how counterpoint is used is illustrated in Figure 2.1., which is in Segment I on page five, from mm. $17-20$ in the winds the oboe player is continuing a melodic figure that is heard in variation in the English horn, and the piccolos, and many of them are rhythmically imitated.

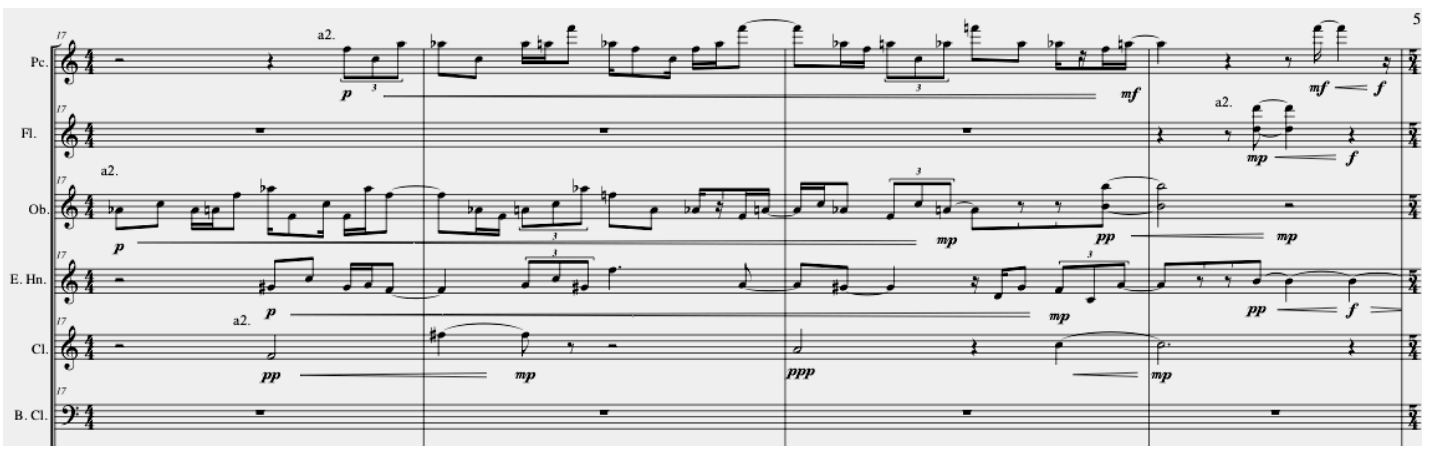

Figure 2.1. Example of a rhythmic imitation from May-SHEE-Ka from Aztlan

I use variation on returning material, but it is usually fragmented and / or interpolated in some way. The text set to the SATB choir in this composition is the translated poem Song of Nezahuaalpilli During the War With Huexotzinco from the book Fifteen Poets of the Aztec World. ${ }^{44}$ These types of poems are considered "song of sadness" and were created by Nezahuaalpilli the Lord of Tezcoco who at eight years of

${ }^{44}$ Miguel León Portilla, Fifteen Poets of the Aztec World. (Norman: University of Oklahoma Press, 1992), 121 - 130. Nezahuaalpilli was the Lord of Tezcoco at eight years of age when he began his reign, and ruled forty-four years. His life was short with relation to other Mexica lords of Tezcoco, but his accomplishments as lord were "far reaching." It is written that he died of grief at 51 years of age because Motecuhzoma used treason against him 
age began his reign. I use a section of this poem, but fragmented, along with the words "tlahtoa cualli" from the Nahuatl language, which translates to "to speak something good." Hockets are used with a minimalistic approach to repetition to create forward propulsion of material. This becomes and additive process in the wind and brass sections through instrument entrances over time in tandem with the hocketing sections of the choir, as shown in Figure 2.2. 

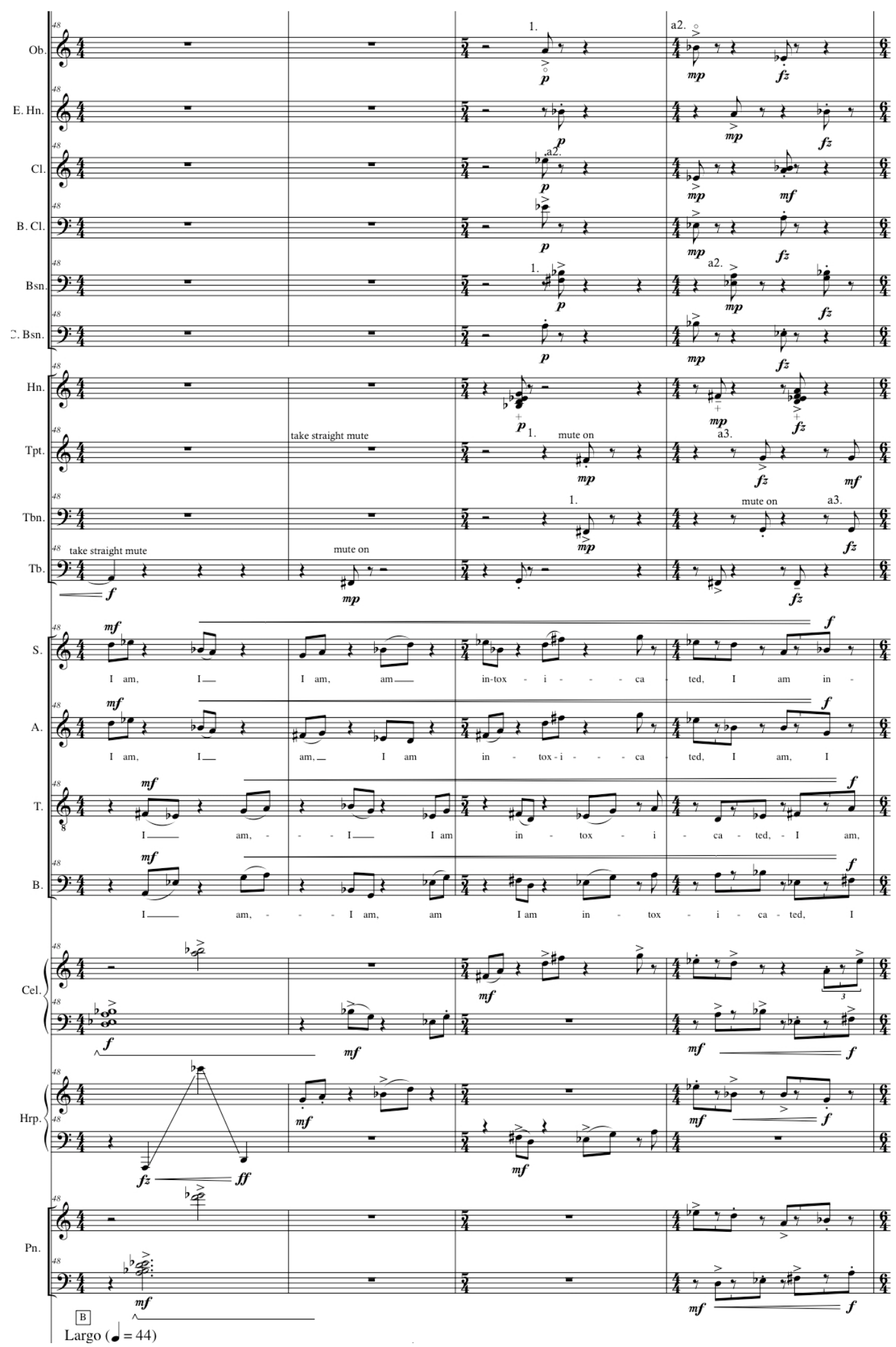

Figure 2.2. Example of an additive process within a hocket from May-SHEE-Ka from Aztlan 
These hockets form several polyrhythmic structures throughout the composition. The polyrhythmic structures used place the emphasis on the primitive ritual quality of percussive rhythms. These structures are used to create momentum and include large accumulations of instruments, which increase in intensity as in mm. $48-55,115-134$, and 165 - 178. Figure 2.3. includes an example of this in segment IV just as the music reaches a climactic crescendo signaling the beginning of the last segment in $\mathrm{m} .179$. Here large complex textures are created with the use of the underlying polyrhythmic structures that occur throughout the orchestra. 


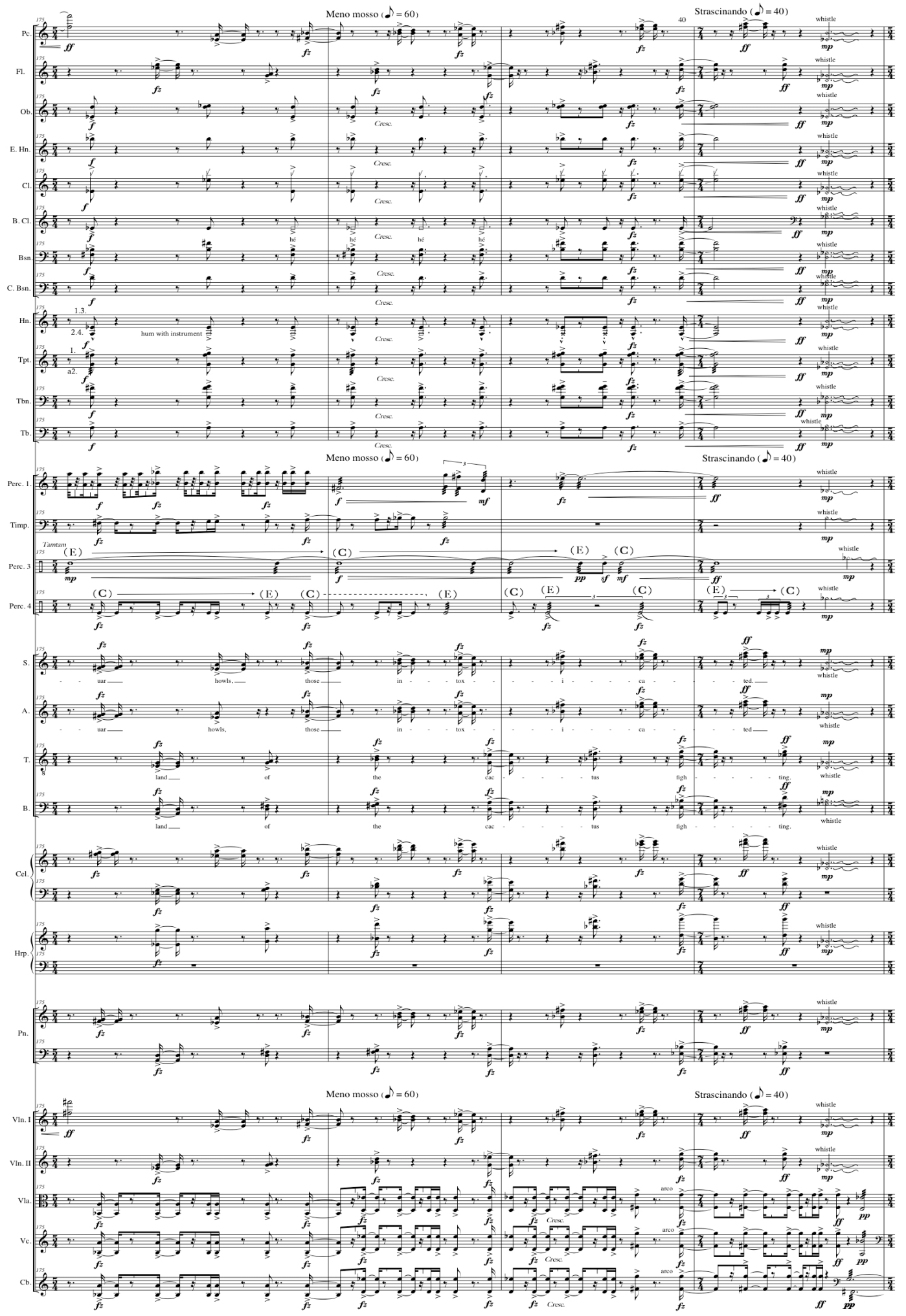

Figure 2.3. Example of a climactic polyrhythmic structure from May-SHEE-Ka from Atzlan 


\section{ORCHESTRATION TECHNIQUES}

The instrumentation for May-SHEE-Ka from Aztlan includes 2 piccolos, 2 flutes, 2 oboes, an English horn, 2 clarinets, a bass clarinet, 2 bassoons, a contrabassoon, 4 French horns, 3 trumpets, 3 trombones, a tuba, 4 percussionist including 2 sets of timpani, SATB choir, celesta, harp, piano, $141^{\text {st }}$ violins, $122^{\text {nd }}$ violins, 10 violas, 8 cellos, and 6 contrabasses. Percussionist 1 plays pitched instruments including glockenspiel, xylophone, vibraphone, tubular bells, and crotales. Percussionist 2 plays timpani exclusively; Percussionist 3 plays tamtam, suspended cymbal, snare drum, congas, claves, and maracas. Percussionist 4 plays bass drum, bongos, temple blocks, triangle, lions roar, slapstick and maracas. Instrumental effects utilized include multiphonics in the piccolos, flutes and oboes; jet whistles, whistle tone multiphonics, tongue pizzicatos, and key clicks, in the piccolo and flute; tongue rams, ghost tones in the flute; trumpet sounds in the piccolo; humming and singing on given pitch in the piccolo, flute, clarinet, French horn, trumpet and trombone; flutter tongue in the piccolo, flute, clarinet, French horn, trumpet and trombone; squawking and teeth on reed in the clarinet; split tongue in the French horns; circular bowing, extreme sul ponticello on top of the bridge, jeté and Bartók pizzicato for the strings; and whistling in the all of the orchestral players except the viola, cello, and contrabass players. Figure 3.1. and 3.2. show the notation I use for a number of these effects. Detailed notation for each of the effects is presented and explained in the score. 


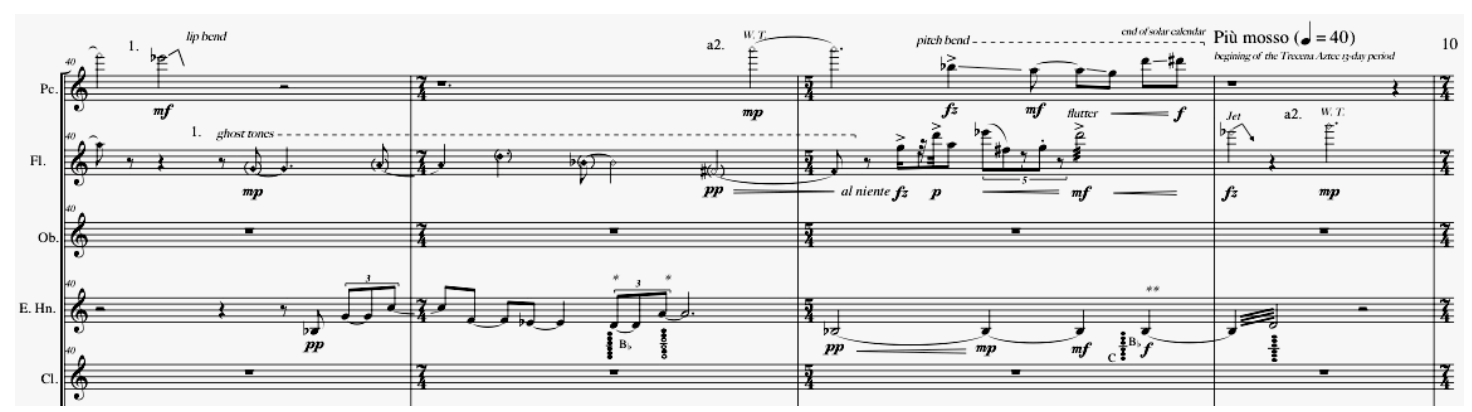

Figure 3.1. Examples of ghost and whistle tone multiphonics, jet whistles, and multiphonic tremolos in the piccolo, flute, and English horn.

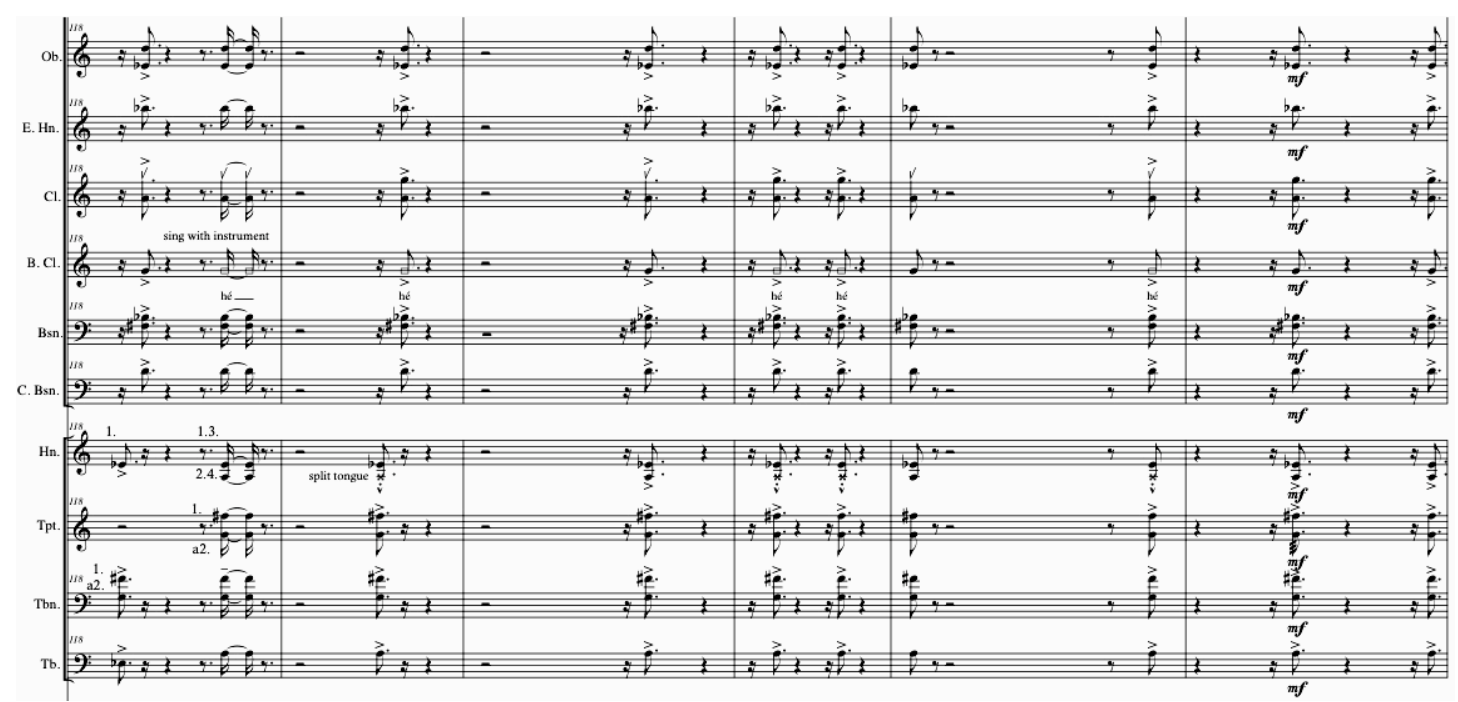

Figure 3.2. Examples of teeth on reed, singing with instrument, and split tongue techniques in the clarinet, bass clarinet, and French horn.

The piece opens with percussion, tuba, 3 trombones and the SATB choir using the Mexica pentatonic scale (MP), combined with the synthetic "May-SHE-Ka scale" (MS). The MS scale is used in the soprano voice, flute and piccolo lines in mm. $3-8$. This same scale is foreshadowed in the piano on beat two of m.1, which also provides notes for the choir. In the piano all of the notes of the MP scale are played and introduced. These notes set up the timbral world of the piece that connects to the idea of the ancient Mexica sound world. Against this the synthetic MS scale is introduced in the celesta. The MS scale provides a timbral sound response that represents the new and 
contemporized idea in this piece. These pitches from the celesta are presented as an immediate counterpoint to the pitches just sounded in the piano.

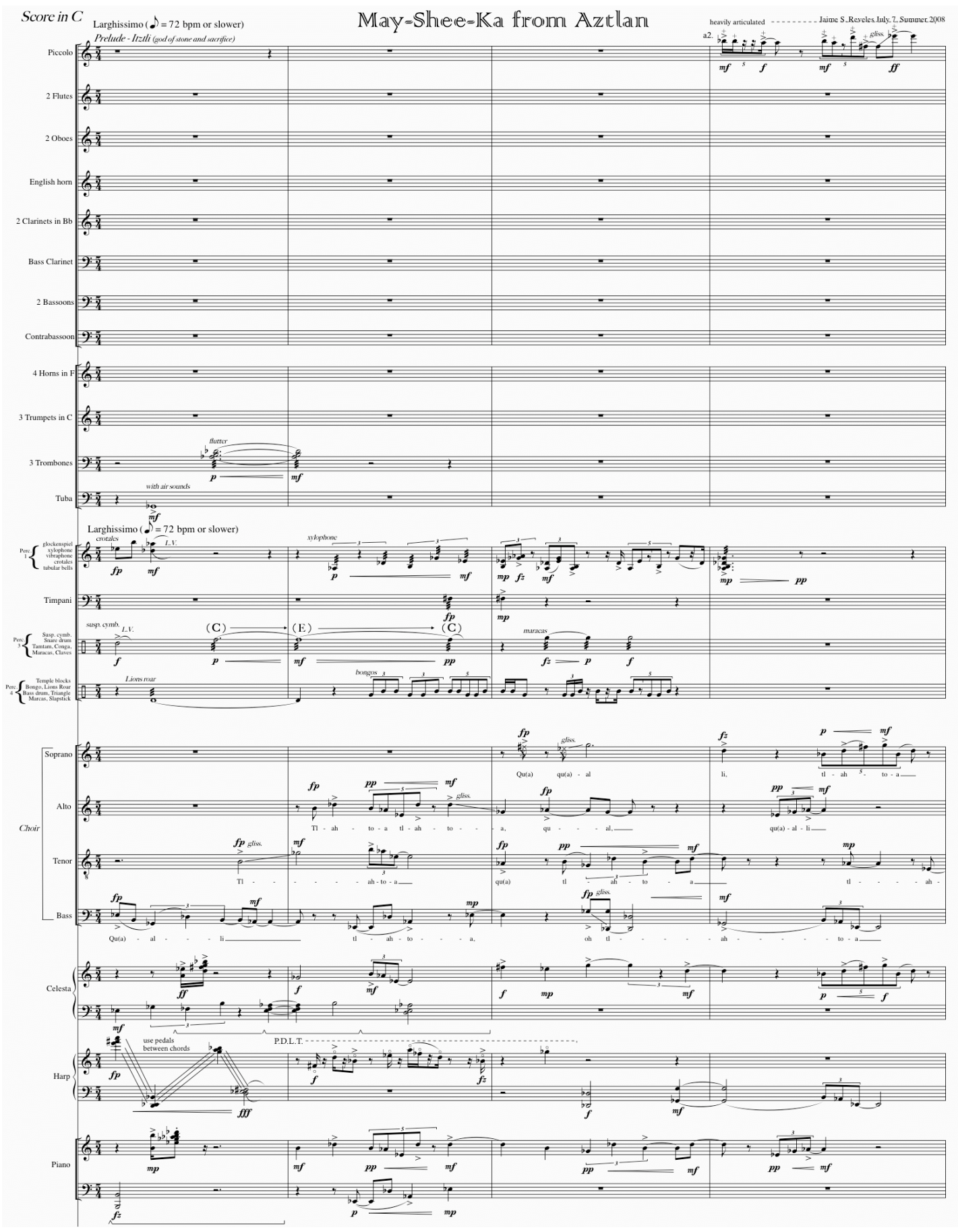

Figure 3.3. An example the opening combination of the MP, and MS scales from May-SHEE-Ka from Aztlan 
Figure 3.3. is an example of how I combine both MP, and MS scales to associate the MP scale to my image of a historical past of the Mexica people of legend. This is juxtaposed with the MS scale that represents my interpreted perception of the Mexica in a new reality. As an orchestral technique I use this approach to highlight the idea of a historical past with the use of the MP scale, which I relate to the legend of the Mexica people. This is contrasted by using the MS scale to represent the Mexica in a new reality from my perception of their darker-side. Orchestrally I use both scales to create a specific color or sound world in my composition. Note that both the MP scale and the MS scale share the common note of, Eb and Gb, but spelled enharmonically as F\# in the MS scale. At the onset both the piano and the celesta express this commonality, which foreshadows to some degree a coming together of the two scales as a large cluster. This is expressed in all of the orchestra later at $\mathrm{mm} .71-74$, because the notes are presented early in the listener's ear to prepare the cluster of the combined MP and MS scales.

Extended techniques are used in the percussion. In the tamtam, large suspended cymbal, and bass drum the playing surface areas are zoned $(\mathrm{C})$ to play at center, $(\mathrm{E})$ to play at the edge, and or moving between these two zones. I group instruments symmetrically splitting instruments from their perspective sections and have them doubling pitches. As I mentioned earlier in the chapter titled "Overview Structure and Texture," I organize instruments and families of instruments in bilateral symmetry. For details of these examples look at Appendix B and D for all grouping and places in the piece where bilateral symmetry occur. I explore other effects with dynamics, articulation and quasi-speaking text for voice parts. 
Segment III begins in m. 57, where I explore a more sparse area texturally. Timbrally this area is more varied because of the many multiphonics and microtones that are played by the piccolo, flute, and English horn players. Selected partials emphasized in the clarinet parts sound because of "squawking" in the instrument starting at m. 56. In the choir the alto, soprano, and tenor singers reinforce these partials in $\mathrm{mm} .55-57$ by whistling. In $\mathrm{m} .73$ the MP scale is emphasized with a timbral block utilizing the pentatonic scale in a cluster chord that is rhythmically supported in the wind and brass sections. I unify the cluster chord is with a forzando in bilateral symmetry (see Appendix B for the assignment of instruments in bilateral symmetry) on beat five of this measure. This begins the reference to the whimsical side of the Mexica. 


\section{BASIC TECHNIQUES}

May-SHEE-Ka from Aztlan is based on two scales that I have instruments perform independently most of the time, although I have moments when these scales intersect or overlap in performance. I use the interval content from the MP scale to focus on major seconds, minor thirds, and major thirds. The intervals of the MS scale centers on minor seconds, major third, and minor thirds. I spread intervals out where the two scales intersect to create more compound harmonies. In this section I begin to utilize an idea taken from the Mexica concept of duality, which was represented in every aspect of their existence. In their religion, pictographs, art, pottery sculptures, and in their architect all exemplified bilateral symmetry. For them everything had its mirror image or dual-side, e.g. sun / moon, hot / cold, good / bad, east / west, north / south etc. I take this idea and apply it to music in various ways. My intention is not to create exact symmetry. Instead I am more concerned with using the idea of duality and bilateral symmetry as an aesthetic technique for organizing timbre and color in sections of this work. I use my own intuitive approach to deciding where when and how to employ this concept.

At $\mathrm{m} .45$ the choir bass singers begins the entrance of the choir. By m. $48 \mathrm{I}$ have the entire choir introduces material in hocket. The text is repeated from what the alto singers recited earlier in mm. $34-6$ "I am intoxicated," which is the beginning of the poem Song of Nezahuaalpilli During the War With Huexotzinco. Here the poem is recited in counterpoint with rhythmic imitation using the MS scale as opposed to the hocketing that will come later. From mm. 48 - 51 in Figure 4.1. the sopranos and altos come in on the strong beats while the tenors and basses come in on the weak beats sometimes in harmonic unison and other times in contrary motion. 
This technique is used to hearken back to my image of a primitive percussive pulse.

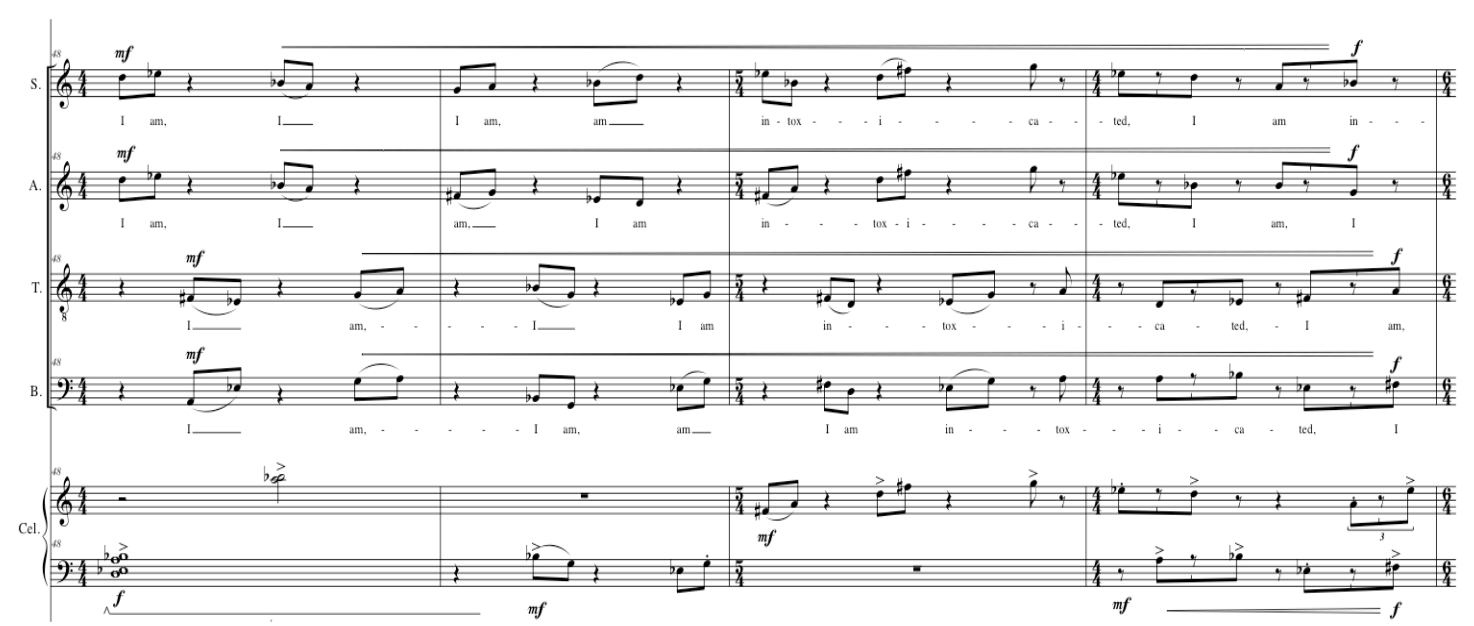

Figure 4.1. Example of pitch organization and rhythmic detail from May-SHEE-Ka from Aztlan

I use the brass section to support the choir tenors and basses rhythmically on beats two and four with an F\# and $\mathrm{G}$ at $\mathrm{mm} .49-51$. I use this to create the rhythmic pattern in both the brass section and the tenor and bass sections of the choir. The bass and tenor sections here are one beat behind the soprano and alto sections. In these measures I use the winds without the piccolos and flutes, to support the soprano and alto singers in the same method. In the percussion discrete hand gestures are requested for playing the bongos and congas, which include resting the hand on the head of the drum and dropping the fingertips while the heel of the hand remains on the head, palming the whole hand to create bass hits, slapping with the fingertips in the rim and muting. This is to support my view of a ritual-like primitive pulse created to reference the percussive nature of the Mexica musical practices mentioned earlier. 


\section{VERTICAL MODELS}

The significant vertical structures in May-SHEE-Ka from Aztlan are a result of overlapping instrumental lines created using the MP, and MS scales throughout the composition. Harmonies result from melodic movement in individual lines of the instruments. There are moments where a clear movement to a cadence is heard. I created these moments to emphasize the sound world that the piece is in at that specific instant. I do this to focus on the reference of the ancient sound world of the Mexica in mm. $71-74$ by having the players in the orchestra move to the large pentatonic block chord at $\mathrm{m} .73$. This begins the whimsical side of the Aztecs I mentioned earlier. Here I use the choir to focus on the fragmented text from the Aztec poem, which begins somber but eventually I turn it dark in nature. This is presented with the pentatonic sound world I set up for this composition. Many of the chords that are consequently built out of rhythmic structures are created to help move the orchestra forward. I have them focus on timbre blocks much like what Luciano Berio accomplishes in his orchestral work Formazioni. ${ }^{45}$

Berio creates polyrhythmic structures that build tension and create a momentum in his orchestral sections. In my composition I use rhythm in combination with pitch material to build large chords through the brass and wind sections to establish the vertical movement that I use to propel this section. On page three of Berio's Formazioni leading up to rehearsal number [1] he creates sets of instrument to organize the orchestra. Figure 5.1. contains an illustration of this. Sets B1 and B2 consist of brass sections that play 16th-note polyrhythmic structures in counterpoint.

\footnotetext{
45 Luciano Berio, Formazioni: Per Orchestra 1985-1987. (Wien: Universal, 2001), 1.
} 
Similarly percussion 1,2 , and 3 play 16 th-note rhythmic counterpoint. In this same section the string players are sustaining longer note figures along with the winds of the A2 set.

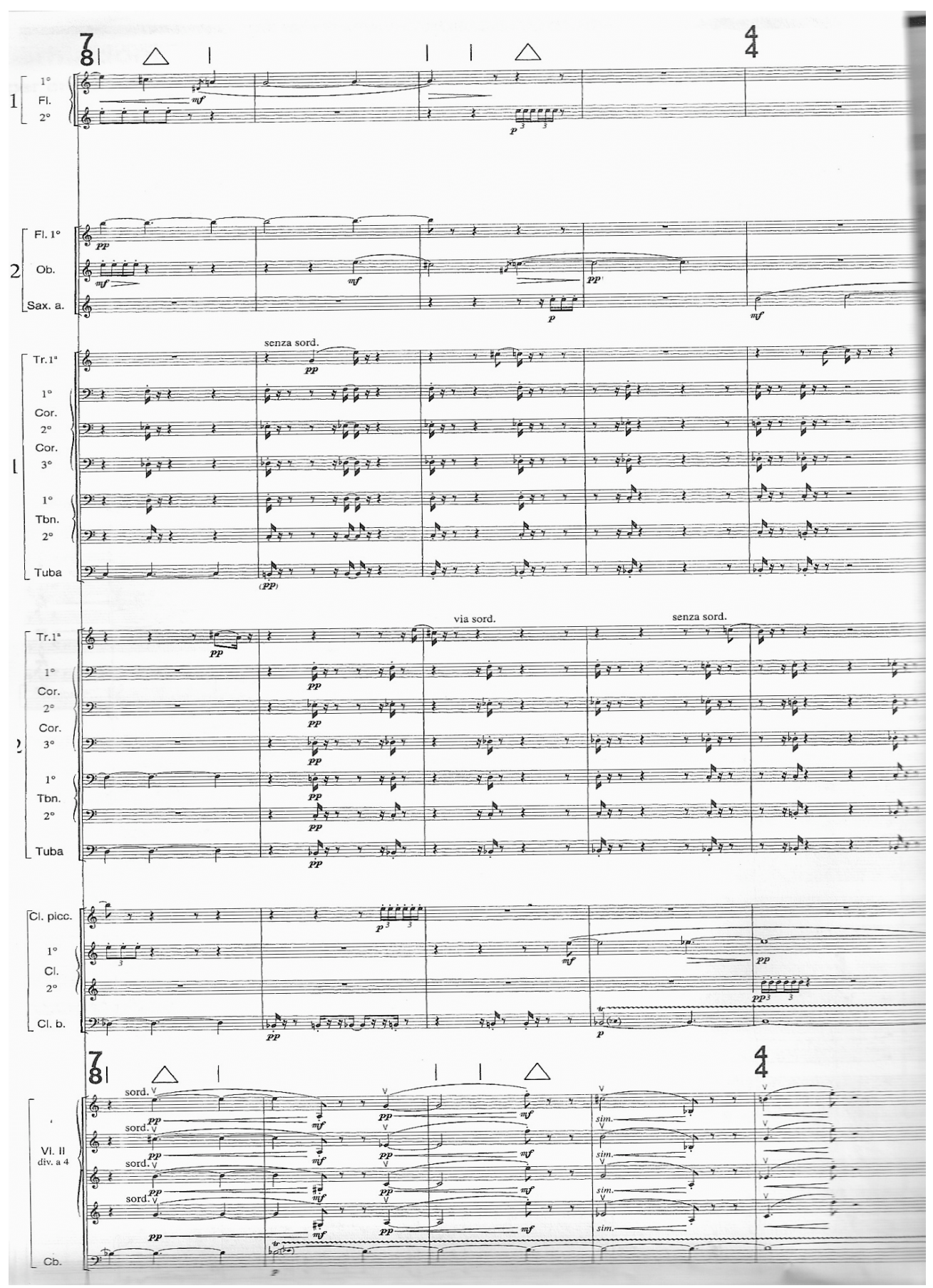

Figure 5.1. Berio's polyrhythmic orchestration from Formazioni 
I model some of the rhythmic structures in my composition from this example of Berio's Formazioni. I create forward propulsion in mm. 118 - 123 with overlapping rhythms.

The harmonic material here is based on the MS scale, which I use as a way to focuses on the more dissonant aspects of this piece as contrast. The harmonic result of the rhythmic structures I use is illustrated in Figure 5.2.

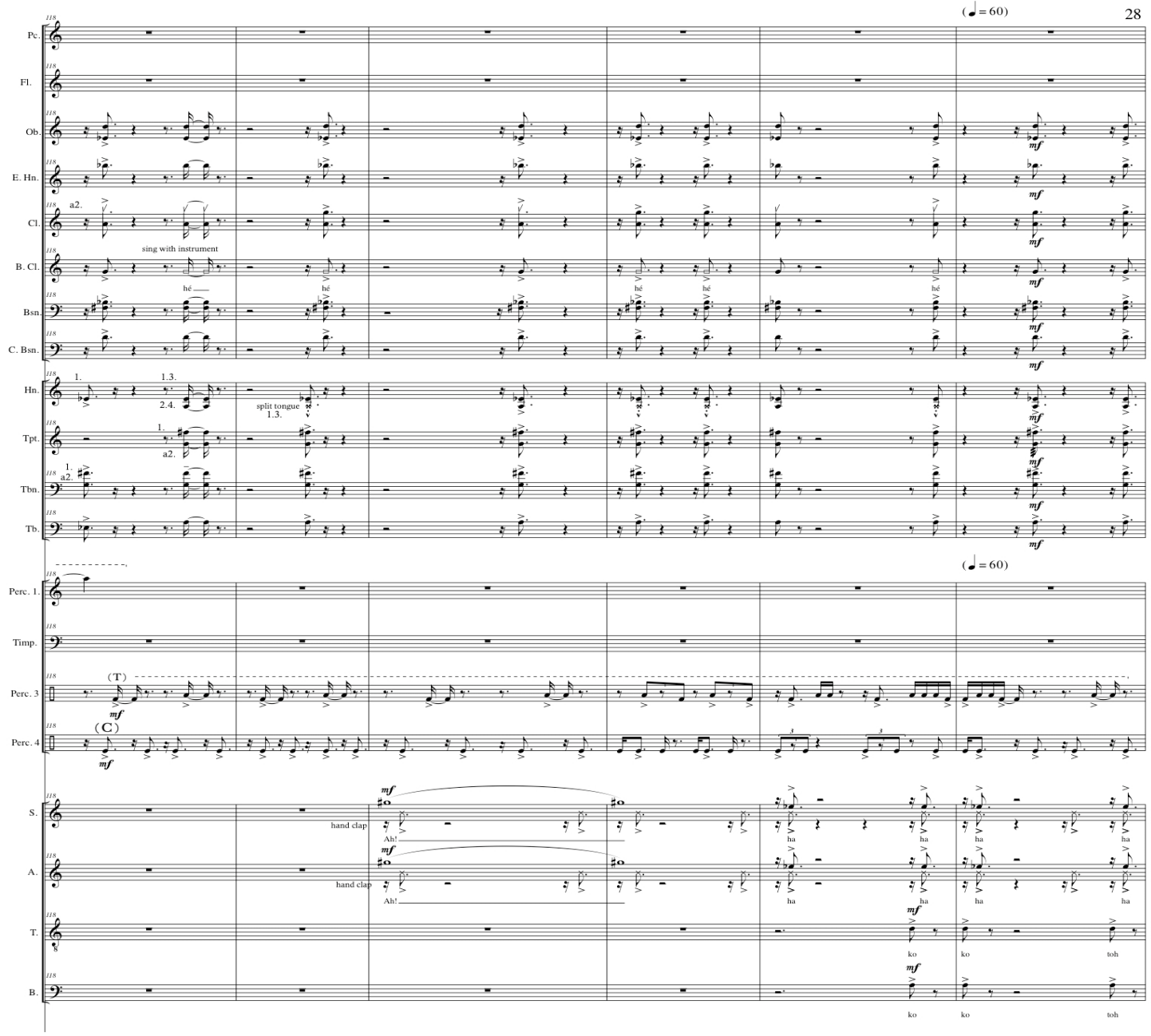

Figure 5.2. A harmonic rhythmic structure from May-SHEE-Ka from Aztlan

Prior to this rhythmic development a large chord cluster of the MS scale was

foreshadowed in $\mathrm{m} .104$. I extend this to a longer duration in $\mathrm{mm} .112-113$. Here the chord was sustained for two measures at the Largo $\downarrow=44$. 
This chord cluster was built by alternating the pitches from the MP scale with the MS scale.

Mexica instrumental music was always accompanied with singing, and this was a vital part of their collective and communal expression. ${ }^{46}$ This inspired me to include a SATB choir in May-SHEE-Ka from Aztlan. I looked at Berio's work Sinfonia For Eight Voices and Orchestra as a model for some of my approaches to setting text. ${ }^{47}$ In movement II $O$ King of Sinfonia Berio overlaps voice entrances with the use of voice phonemes, which create whole-tone harmonies that are accentuated with the brass strings and piano. Although the voices are amplified in this piece, Berio has dynamics for the first nine pages at sempre $p p p p$ except for the soprano 1 who is at $p p p$, which adds to the harmonic tension that build through this section. Berio's approach to setting text uses melodic movement with harmonic structure. An example of this is illustrated in Figure 6.3 .

${ }^{46}$ Robert Stevenson, and Arturo Chamorro. "Aztec music, " In Grove Music Online. (Accessed September 30, 2008).

${ }^{47}$ Luciano Berio, Sinfonia: For Eight Voices and Orchestra 1968. (London: Universal Edition, 1972), 27. 


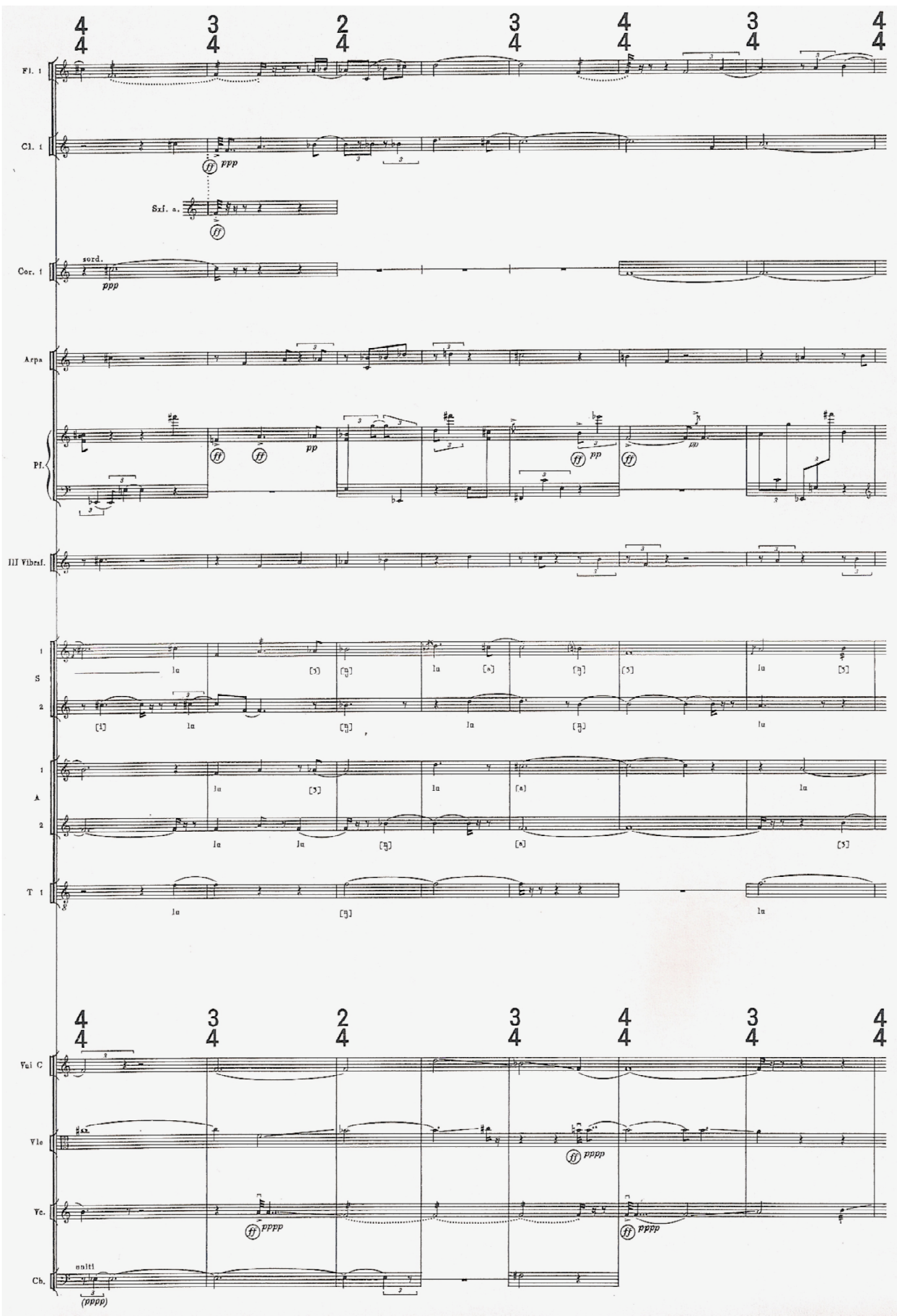

Figure 5.3. Berio's Sinfonia: For Eight Voices and Orchestra movement II O King 
This approach to overlapping voice lines is modeled similarly in my composition May-SHEE-Ka from Aztlan in mm. 73 - 91. Harmonies develop out of the MP scale, which are made up of major seconds, minor thirds, major thirds and perfect fourths. From mm. $84-86$ I form chords out of these intervals to stress the whimsical sound world of the Aztecs.

Lachenmann's Ausklang: Musik für Klavier mit Orcheste ${ }^{48}$ is an example of how the sustenuto pedal of the piano can be utilized to color the other pitches that are not sounded directly with the hammers of the piano. The vibrations of the notes sounded on the keys excite these notes. This technique is illustrated in Figure 5.4. I use this extended technique in my composition to create various masses of sound and texture.

48 Helmut Lachenmann, Ausklang: Musik für Klavier mit Orcheste. (Wiesbaden: Breitkopf \& Härtel, 1986), 2. 


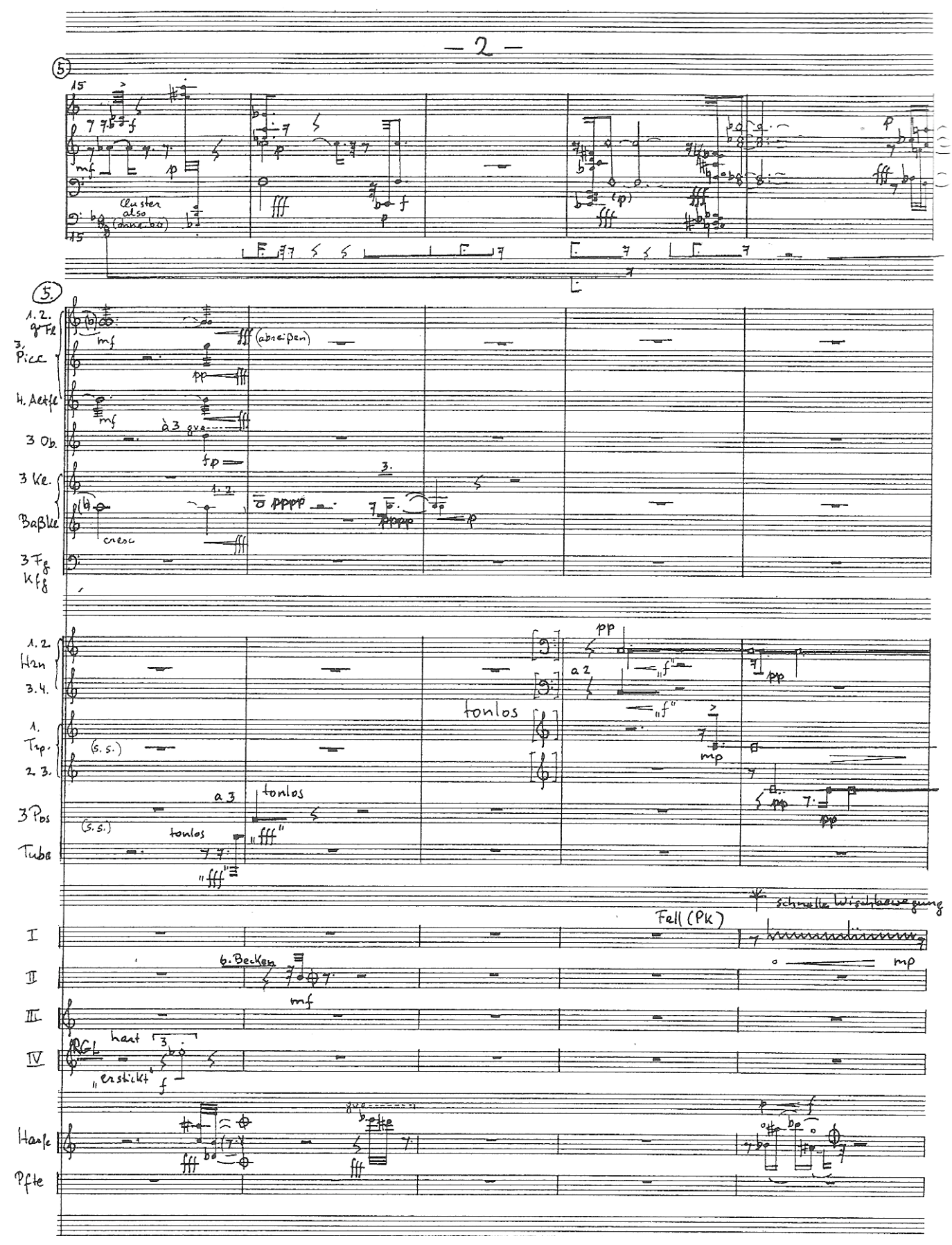

Figure 5.4a. Helmut Lachenmann's Ausklang: Musik für Klavier mit Orcheste

An example of this is highlighted in Figure 5.4. in the piano section where Lachenmann uses specific marking for the sostenuto pedal. In $\mathrm{m}$. 15 he uses two horizontal beamed 
lines for piano pedaling, the thicker line is for the right sustain pedal, and a thinner line for the sostenuto pedal. This line is attached to the diamond-headed notes.

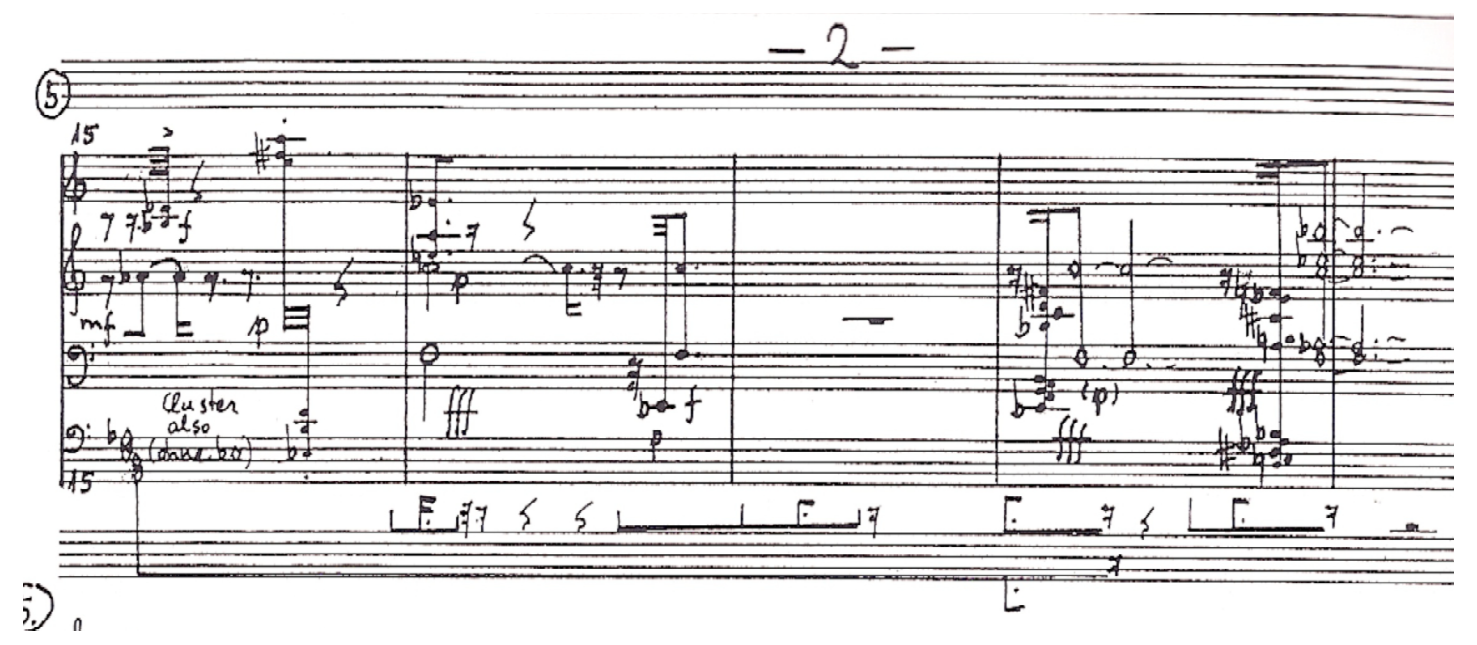

Figure 5.4b. Sostenuto pedaling from Lachenmann's Ausklang: Musik für Klavier mit Orcheste

He has the sostenuto pedal depressed only on these specific notes. What Lacenmann is requesting the solo pianist here is to silently depress the diamond-headed notes while depressing the sostenuto pedal. The other notes of the piano part are performed over this. This process excites the diamond-headed notes with their overtones, creating a sonic cluster.

In my composition May-SHEE-Ka from Aztlan I use this approach to creating overtone spectral clusters as a way to explore my imagined idea of all the possible overtone partials that were a result of playing many of the Aztec's wind instruments. I utilize Lachenmann's idea for the use of the sostenuto pedal, although in my composition the note heads that represent the silent depressed notes are square, and the horizontal pedal lines are illustrated differently. An example of how this is employed in the score is illustrated in Figure 5.5. I explore the orchestral technique of using the sostenuto pedal in 
this way through out all of my composition to emphasize specific tones sounding in different instruments of the orchestra at particular moments.

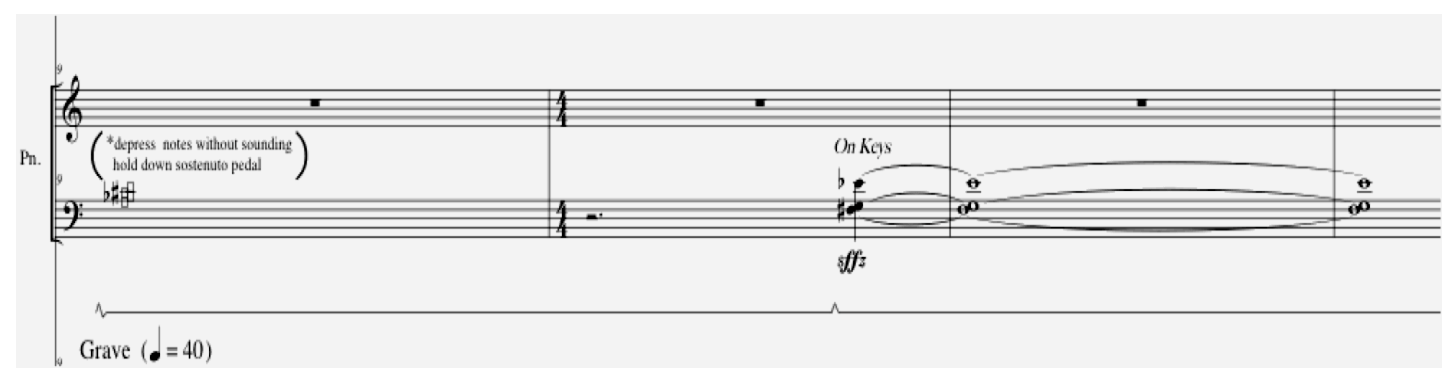

Figure 5.5. An illustration of the sostenuto pedaling from May-SHEE-Ka from Aztlan

In the example on mm. 9 - 12 I have the piano player depressing $\mathrm{A}, \mathrm{B}, \mathrm{C} \# \mathrm{D}$ notes with the sostenuto pedal on the down-beat of m. 9, on beat three of m. 10 notes F\#, G and $\mathrm{Eb}$ are to sounded for the aforementioned effect of resonance these notes with their overtones provide. 


\section{HORIZONTAL MODELS}

In May-SHEE-Ka from Aztlan, I modeled segments I mm. 9 - 32, segment IV mm. 164 175 and in the string section of segment V mm. 179 - 207 after Arnold Schoenberg's Five Pieces for Orchestra, op. 16, movements I Vorgefühle, and III Farben (1909), revised 1922, 1949. ${ }^{49}$ In this atonal work Schoenberg employs the technique of "Klangfarbenmelodie" (Gr. "tone-color-melody"), a term he coined. In this technique musical lines and melodies are divided up from one instrument to another and circulated between several other instruments. In movement I Vorgefühl, his harmonic language is based on perfect fourths and fifths, tritones, and augmented triads. In movement III Farben the harmonic language is based on quartal and quintal harmony that shifts slowly with descending seconds. In mm. 41 - 43 of movement I Vorgefühle below in Figure 6.1. Schoenberg writes a rhythmic melody that begins with the piccolo, and flute players together with the D-clarinet players doubled in octaves on D, and F\#. In a similar fashion I have the melody move chromatically down until the last beat of m. 42 in the low register of flute II. The English, and French horn players join in to end this melody in $\mathrm{m}$. 43. The use of Klangfarbenmelodie, adds more timbral color to the orchestration as opposed to having only one instrument-timbre playing a single melody.

${ }^{49}$ Arnold Schoenberg, Fünf Orchesterstücke: Originalfassung, Five pieces for orchestra : original version, op. 16. (London: Eulenburg, 1950). 


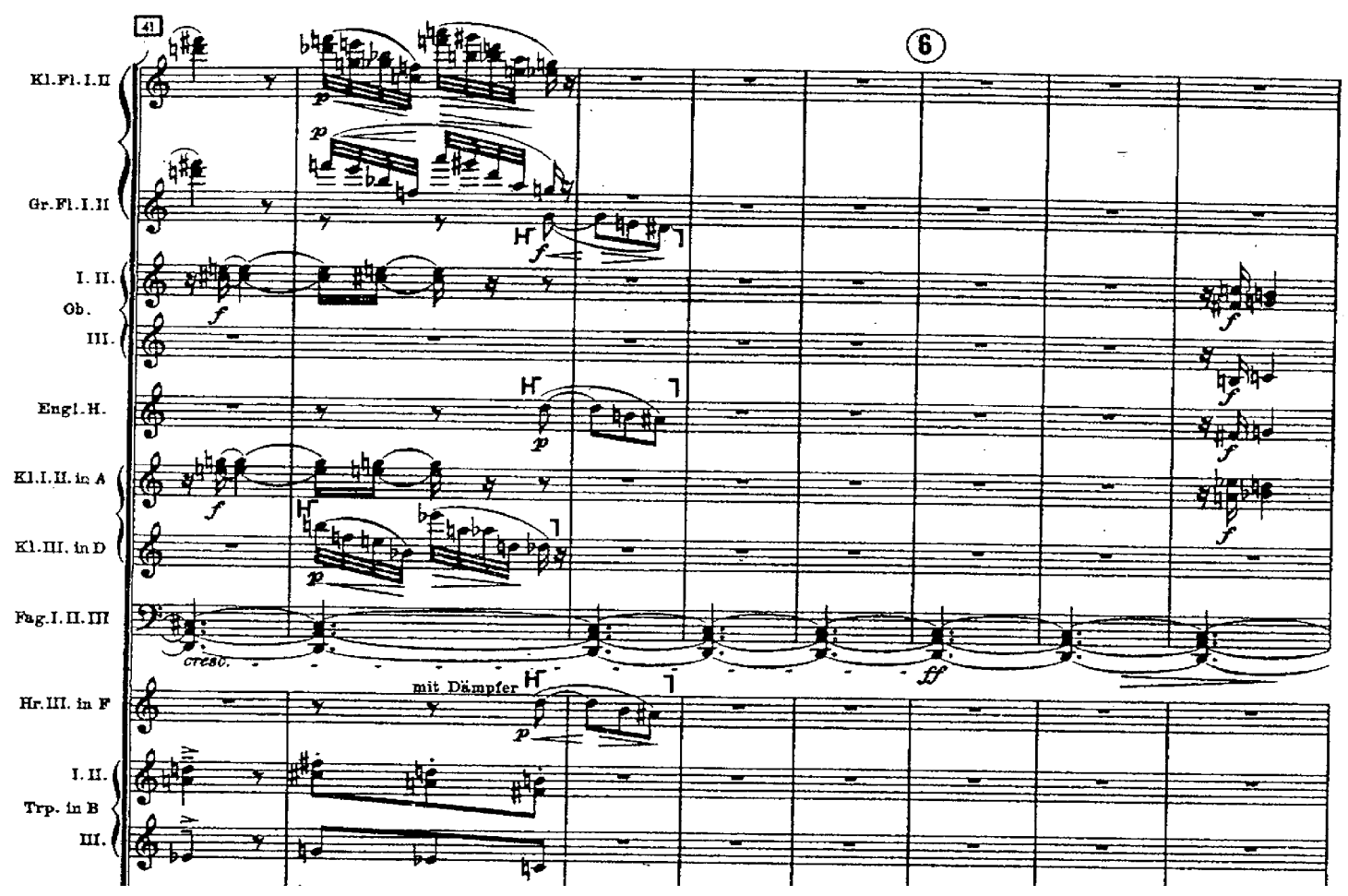

Figure 6.1. Schoenberg's use of Klangfarbenmelodie from Five Pieces for Orchestra, op. 16 movement I Vorgefühle

In movement III Farben, Schoenberg employs Klangfarben more notably with sustained notes. Schoenberg still uses fragmented melodies, but much shorter disjunct motives are employed. These melodic fragments are fewer and more deliberate as shown in the examples in Figure 6.2. in m. 227, 229, mm. $240-41$. Movement III Farben is more static with the focus on shifting the color of the orchestra between instruments instead of focusing on changing pitch. The dynamics in this movement are also much softer at $p p p$, to focus attention to the subtle changes in timbre. 


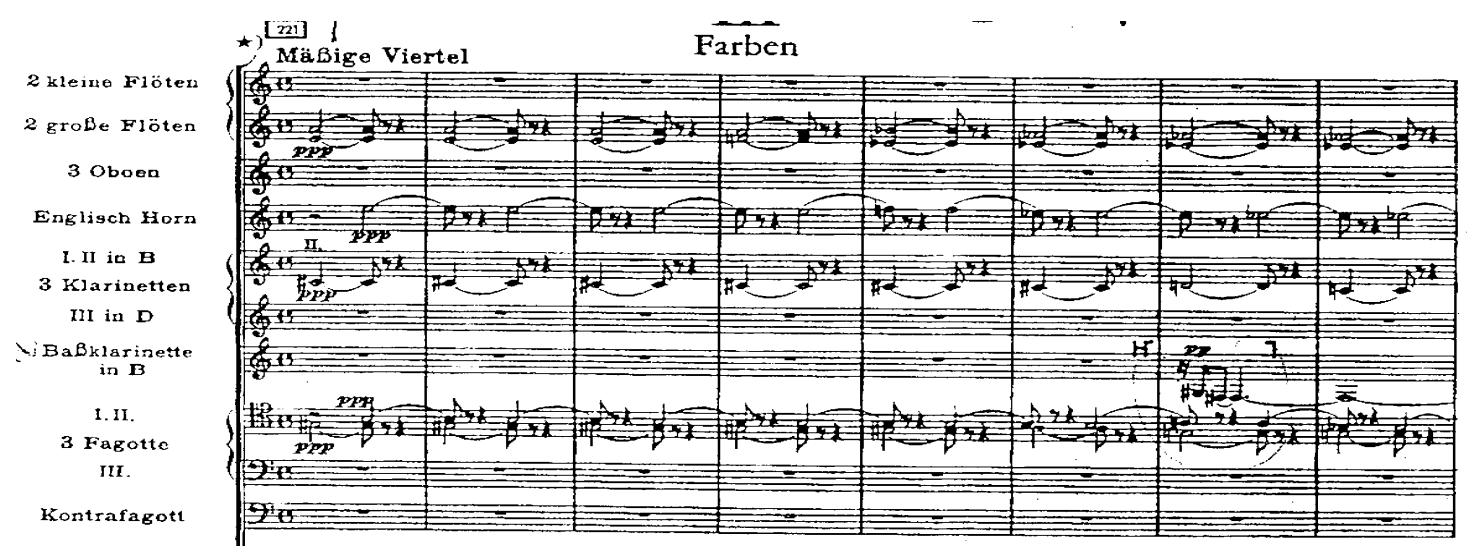

Figure 6.2. Schoenberg's use of Klangfarben from Five Pieces for Orchestra, op. 16. Movement III

Farben

Schoenberg uses Klangfarben in the way traditional composers such as Beethoven used changes in pitch for development. He replaces this methodology through the changing of orchestral color as a way of developing material. Instrumental groups present and perform the same chords that begin in one group of instruments such as the brass in mm. $231-32$ that then move to the woodwinds in m. $232-233$. as shown in Figures 6.3. and 6.4.

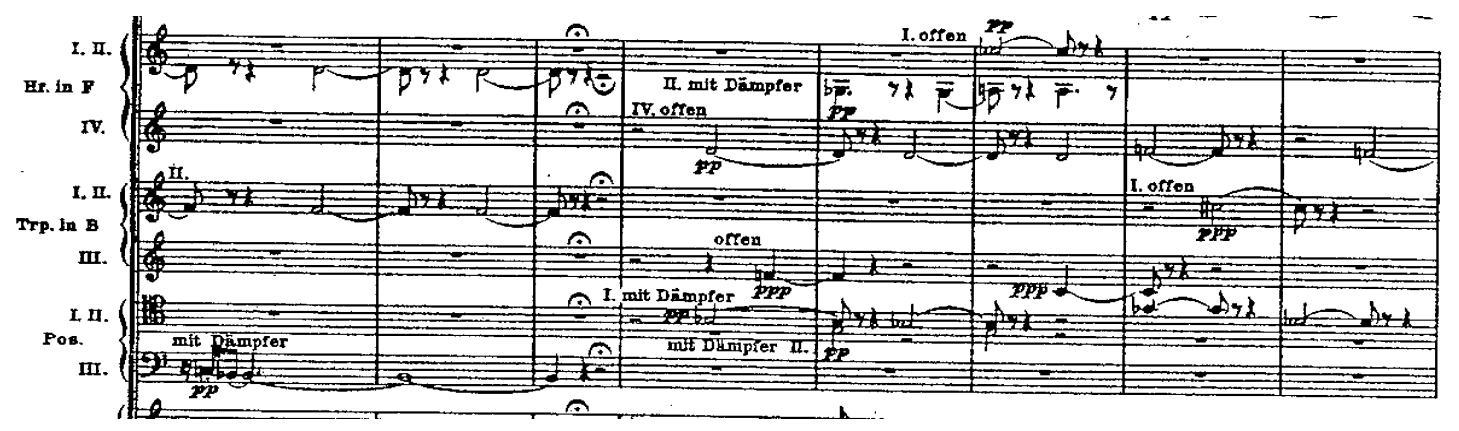

Figure 6.3. Moving chords of color in brass in movement III Farben from Schoenberg's Five Pieces for Orchestra, op. 16 


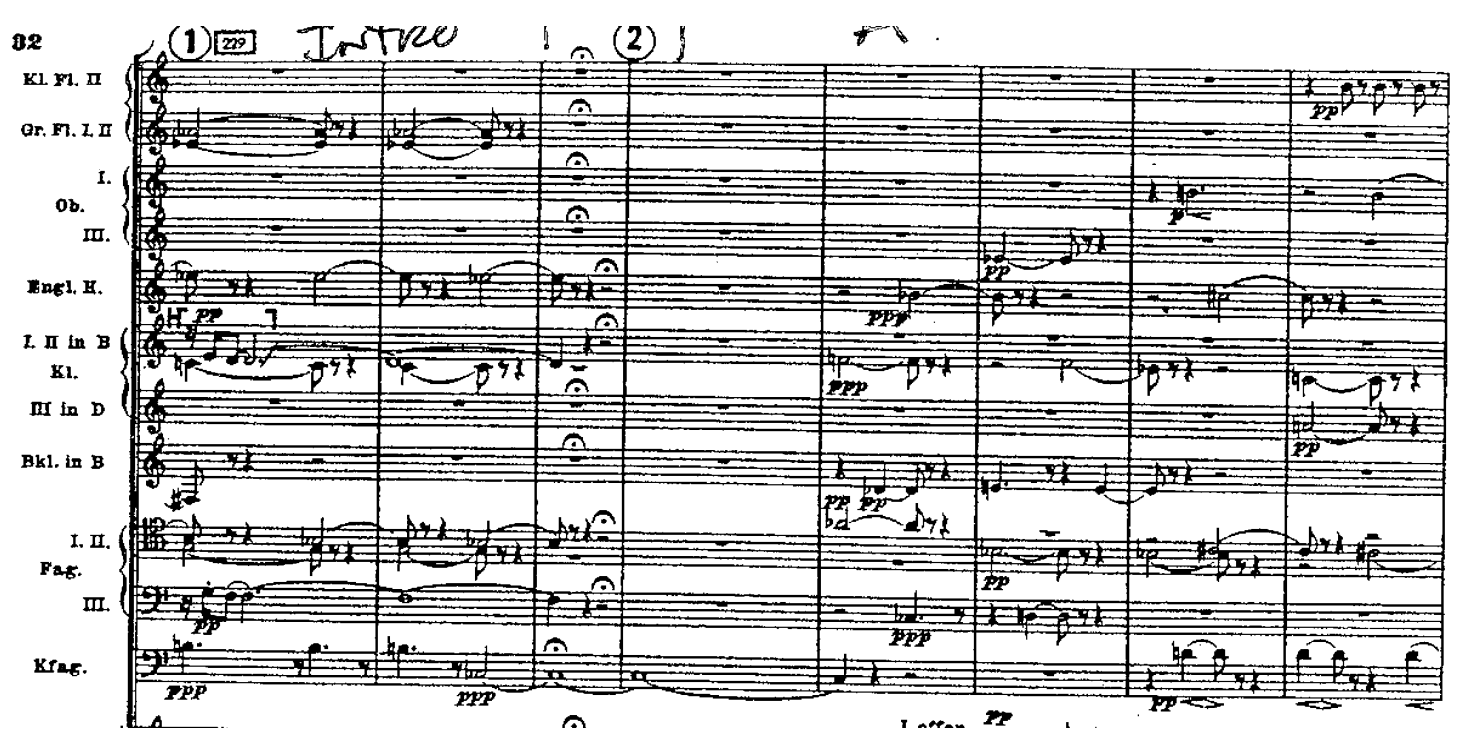

Figure 6.4. Moving chords of color to woodwinds in movement III Farben from Schoenberg's Five Pieces for Orchestra, op. 16

I use Klangbarben as a developmental technique to create a distinct type of "sound-world". In the first segment beginning on page three m. 9, I arrange the instrumental groups to present timbre colors that shift from strings to brass and then to the woodwinds. This occurs this in mm. $9-12,13-16,17-20,21-24$, and $25-28$ of this work. This approach to developing material is illustrated in Figure 6.5. 


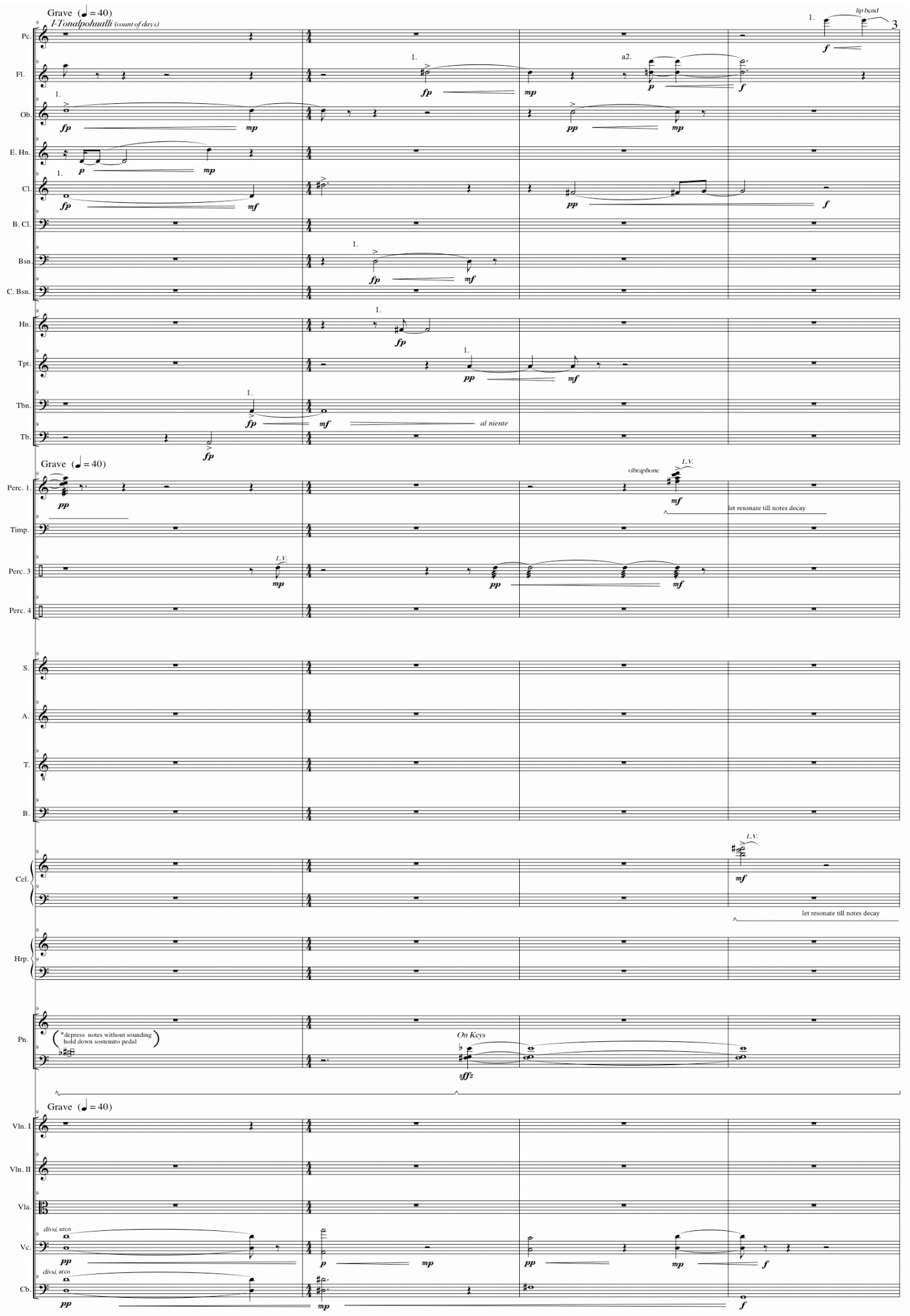

Figure 6.5. An example of tone-coloring from May-SHEE-Ka from Aztlan 
I use Klangfarbenmelodie in segment V of May-SHEE-Ka from Aztlan, throughout mm. $179-198$ in all of the orchestra. The illustration in Figure 6.5. is one example of where I utilize this technique creating two musical melodies that I fragment and spread throughout the orchestra. In mm. 179 - 182 I have the first ascending musical melody presented by one trombone player. This melody is then presented in $\mathrm{m}$. 180 with one trumpet player for one measure, and the melodic line is then transferred to the French horn player in $\mathrm{m} .181$, and then presented by the clarinet player in the first half of $\mathrm{m} .182$. Before the French horn finishes playing the last note in $\mathrm{m} .182$, the piccolo player presents the rest of the musical melody at $\mathrm{m} .181$ to complete the melodic line in $\mathrm{m} .182$. In these same measures I have a second musical melody presented by the oboe player in mm. $179-180$. The clarinet player continues this melodic line and presents it in the first two beats of $\mathrm{m}$. 181, after which the bassoon player presents the next part of the melody in the last two beats of that same measure. This second musical melody ends with the French horn player at m. 182. I continue this technique, by developing and fragmenting these two melodies even more in the $\mathrm{mm} .183$ - 186 but in retrograde presenting them in different instruments. 


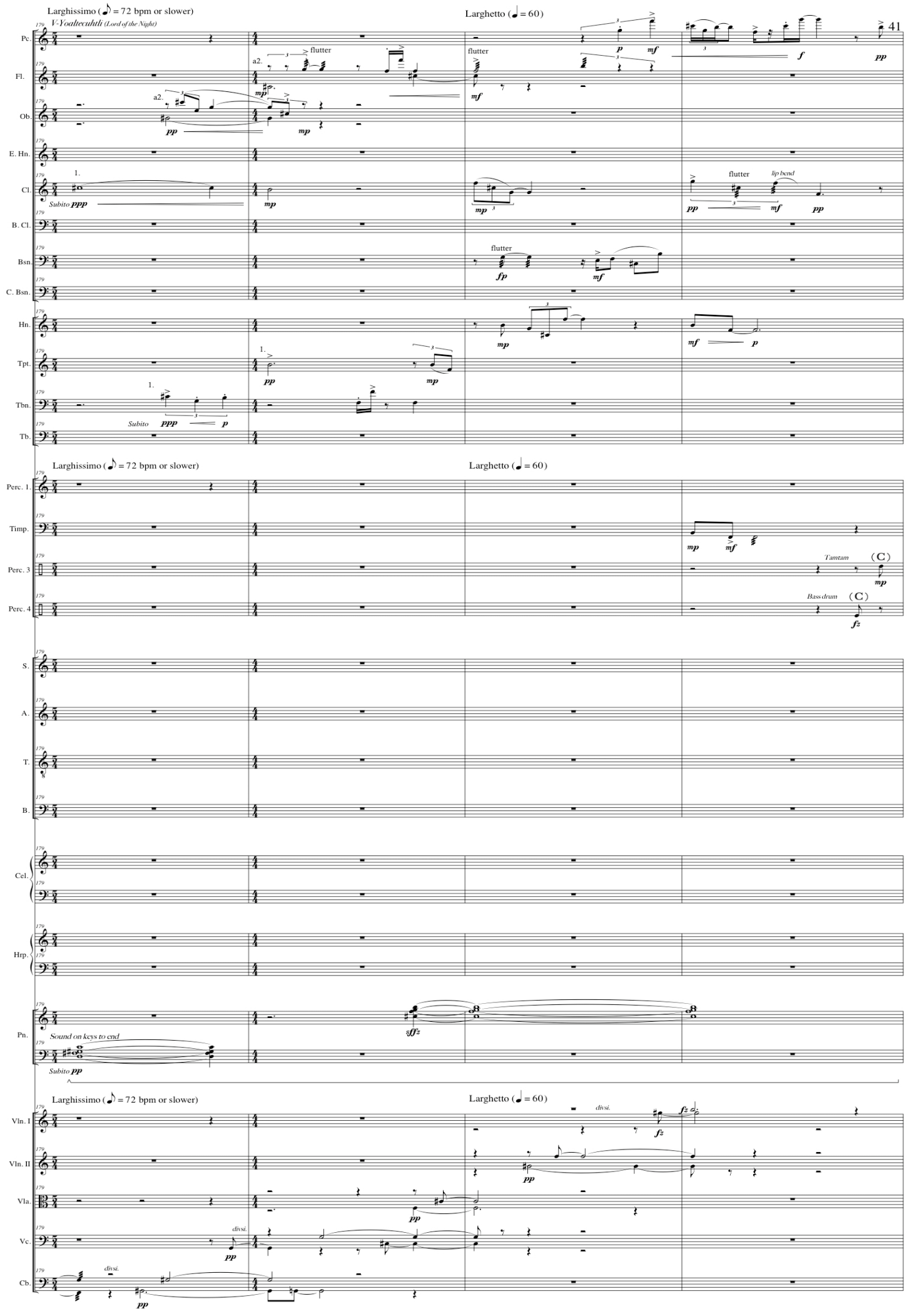

Figure 6.6. An example of Klangfarbenmelodie from May-SHEE-Ka from Aztlan 


\section{STYLE}

My style is very eclectic and highly intuitive in execution. I believe modern music should be concerned with progress characterized by a desire to move music forward intellectually as well as technically to break away from past common practices. By using new and non-traditional techniques in music, I feel I can take my music beyond earlier approaches in composition, to challenge myself to think outside of the traditional " box." This for me is extremely important and worth exploring in all my compositions, not just this work. It is important to look at past modernist composers such as the ones I have mentioned, to see how they propelled music composition forward.

I am concerned with the rich timbres of all instruments that come from traditional playing as well as extended instrumental and vocal techniques. The sound world made accessible by unconventional playing techniques is very interesting to me. I am interested in cultural influences, new unheard of modes of expression, suggestive theatricality, and rich cultivated musical allusions with a sense of resonant detail. MaySHEE-Ka from Aztlan is inspired from my research of my ethnic background, and the Mexica people. My goal was to paint an orchestral landscape, which is influenced by aspects of their historical lives. The sounds of their native instruments (ideas derived from their drums, flutes, trumpets, and ocarinas) were consideration for aspects of my timbral choices regarding instrumentation and the orchestration of the musical material in this composition. Many of the ideas for this composition evolve out of small cells that I work out into larger structures. These cells are most always inspired by a larger metaphor or image in my mind. My approach deals with ideas of catharsis in a personal need to release my emotions of feeling, and share this with others. 


\section{CESSATION CODA}

When I began this piece, the ideas came flowing like the rain of South Florida, in torrids, although there was many a dry day, the overall "big picture" was always clear for me.

I feel that this piece might be expanded in several ways that deal compositionally with ideas associated to the Mexicas numerical importance of the number "13." Adding another movement, which focuses even more on the idea of ritual ceremony, could expand this work. This movement may well combine numerical sets of rhythmic and harmonic figures that would accumulate either independently from each other or combined. In this new addition the score might be proportional and utilize factors of 13 to build collective small and large musical structures that play with perceptions of stretching time. Sections could move between moderate to slow rhythmic pacing with a focus on repeating material, which can be presented rhythmically and/or tonally. I would also like to exploit the idea of using drones as a ground structure where rhythmic material can be processed slowly over time.

One of the best things that came from my creating this work is that I learned I really enjoy writing for orchestra. Out of an exercise to realize the images, and music going on in my minds-eye, I found that the orchestra is perfect place for me to express my ideas through timbre and mass sound. 


\section{BIBLIOGRAPHY}

Adler, Samuel. The Study of Orchestration. New York; W.W. Norton, 2002.

Adorno, Theodor W., and Robert Hullot-Kentor. Philosophy of New Music. Minneapolis: University of Minnesota Press, 2006.

Adorno, Theodor W., Richard D. Leppert, and Susan H. Gillespie. Essays on Music. Berkeley, California: University of California Press, 2002.

Arduini, Franca. The World of the Aztecs, in the Florentine Codex. The library on display, 1. Florence: Mandragora, 2007.

Berio, Luciano. Formazioni: Per Orchestra 1985 - 1987. Wien: Universal, 2001.

Berio, Luciano. Sinfonia: For Eight Voices and Orchestra 1968. London: Universal Edition, 1972.

Black, Dave, and Tom Gerou. Essential Dictionary of Orchestration. Van Nuys, CA: Alfred Publishing Co., 1998.

Blatter, Alfred, and Alfred Blatter. Instrumentation and Orchestration. New York: Schirmer Books, 1997.

Boulez, Pierre. Notations: Pour Orchestre. London: Universal Edition, 1978.

Cadwallader, Allen Clayton, and David Gagné. Analysis of Tonal Music: A Schenkerian Approach. New York; Oxford University Press, 1998.

Carrasco, David, and Scott Sessions. Daily Life of the Aztecs: People of the Sun and Earth. Indianapolis: Hackett Pub. Co, 2008.

Cope, David. New Directions in Music. Long Grove, IL: Waveland Press Inc., 2001.

Crumb, George. A Haunted Landscape: Score. New York: Peters, 1984.

Crumb, George. Variazioni for Large Orchestra. New York: Mills Music Inc, 1959.

Dick, Robert. The Other Flute: A Performance Manual of Contemporary Techniques. 2nd ed. New York: Multiple Breath Music Co., 1989

Hill, Douglas. Extended Techniques for the Horn: A Practical Handbook for Students, Performers and Composers. Miami, Florida: Warner Bros. Publications, 1996.

James, N. Aztecs \& Maya: The Ancient Peoples of Middle America. Stroud, Gloucestershire: Tempus, 2001. 
Kramer, Jonathan D. The Time of Music: New Meanings, New Temporalities, New Listening Strategies. New York: Schirmer Books, 1988.

Kramer, Jonathan D. Time in Contemporary Musical Thought. Chur: Harwood Academic Publishers, 1993.

Lachenmann, Helmut. Ausklang: Musik für Klavier mit Orcheste, music for piano with orchestra. Wiesbaden: Breitkopf \& Härtel, 1986.

Lachenmann, Helmut. Tableau: Für Orchester (For Orchestra). Wiesbaden: Breitkopf \& Härtel, 1989.

León Portilla, Miguel. Fifteen Poets of the Aztec World. Norman: University of Oklahoma Press, 1992.

Lewis, Brenda Ralph. The Aztecs. Sutton Pocket Histories. Stroud: Sutton Pub, 1999.

Martens, Frederick H. "Music in the Life of the Aztecs," The Musical Quarterly, Vol. 14, No. 3 (Jul., 1928), Oxford University Press, Stable URL: http://www.jstor.org/stable/738439, (Accessed: 30/09/2008 17:33), 413 - 437.

Miller, Mary Ellen and Karl A.Taube. The Gods and Symbols of Ancient Mexico and the Maya: an Illustrated Dictionary of Mesoamerican Religion. New York: Thames and Hudson, 1993.

Penderecki, Krzysztof. Passion According to St. Luke: (Passionmusik Nach Lukas). Celle: Moeck, 1967.

Rehfeldt, Phillip. New Directions for Clarinet. The New Instrumentation. Lanham, MD: Scarecrow, 2004.

Sciarrino, Salvatore. Aspern-Suite: Per Soprano e Strumenti. Milano: Ricordi, 1987.

Salzer, Felix. Structural Hearing: Tonal Coherence in Music. New York; Dover Publications, 1982.

Schoenberg, Arnold. Fünf Orchesterstücke: Originalfassung, Five Pieces for Orchestra: Original Version, op. 16. London: Eulenburg, 1950.

Stevenson, Robert, and Arturo Chamorro. "Aztec music." In Grove Music Online. Oxford Music Online, http://www.oxfordmusiconline.com/subscriber/article/grove/music/01636 (accessed September 30, 2008). 
Strange, Patricia, and Allen Strange. The Contemporary Violin: Extended Performance Techniques. Berkeley: University of California Press, 2001.

Straus, Joseph Nathan. Elements of Music. Upper Saddle River, NJ: Pearson Prentice Hall, 2008.

Takemitsu, Toru. Riverrun: for Piano and Orchestra. Mainz: Schott, 1987.

Takemitsu, Toru. November Steps: Orchestra: New York: C.F. Peters, 1967.

Time Magazine. "Aztec music." In Time Magazine Online, Time Inc. http://www.time.com/time/magazine/article/0,9171,884120,00.html (accessed August 13, 2008).

Turetzky, Bertram. The Contemporary Contrabass. Berkeley: University of California Press, 1989.

Van Cleve, Libby. Oboe Unbound: Contemporary Techniques. Lanham, MD: Scarecrow Press, 2004.

Varèse, Edgard. Arcana: for Orchestra. New York: Colfranc Music Pub. Corp, 1964.

Webern, Anton. Symphonie, für Klarinette, Bassklarinette, 2 Hörner, Harfe, 1. und 2. Geige, Bratsche, und Violoncell, op. 21. Wien: Universal Edition, 1929.

Webern, Anton. Sechs Stücke - Six Pieces: Op.6. Wien: Universal, 1928. 


\section{APPENDIX - A}

Segment and Tempo Marking Table

\begin{tabular}{|c|c|c|c|c|}
\hline Segments & $\begin{array}{l}\text { Related Aztec } \\
\text { Name }\end{array}$ & $\begin{array}{c}\text { Measure } \\
\text { Number/s }\end{array}$ & Tempo Markings & $\begin{array}{l}\text { Indication } \\
\text { Definition }\end{array}$ \\
\hline Prelude & $\begin{array}{l}\text { Itztli (god of stone } \\
\text { and sacrifice) }\end{array}$ & $1-8$ & $\begin{array}{l}\text { Larghissimo } q=40 \\
\text { bpm or slower }\end{array}$ & $\begin{array}{l}\text { Extremely Slow } \\
\text { Tempo }\end{array}$ \\
\hline \multirow[t]{7}{*}{ Segment I } & $\begin{array}{l}\text { Tonalpohualli (count } \\
\text { of days) }\end{array}$ & $9-20$ & Grave $\mathrm{q}=40$ & Very Slow and Solemn \\
\hline & & $21-22$ & Meno Mosso e $=60$ & Slower \\
\hline & & $23-24$ & Strascinando e $=40$ & $\begin{array}{l}\text { Getting Gradually } \\
\text { Slower }\end{array}$ \\
\hline & & 25 & Più mosso $\mathrm{q}=40$ & $\begin{array}{l}\text { More Movement or } \\
\text { Faster }\end{array}$ \\
\hline & & 26 & Poco accel. al & $\begin{array}{l}\text { Slowly Accelerate to } \\
\text { Next Tempo Marking }\end{array}$ \\
\hline & & $27-30$ & Lento $\mathrm{q}=52$ & Slow \\
\hline & & $31-32$ & Molto accel. $q=60$ & Much Acceleration \\
\hline \multirow[t]{7}{*}{ Segment II } & $\begin{array}{l}\text { Xihuitl (solar year); } 9 \\
\text { - Tecpatl (flint knife) }\end{array}$ & $33-42$ & $\begin{array}{l}\text { Larghissimo } q=40 \\
\text { bpm or slower }\end{array}$ & $\begin{array}{l}\text { Extremely Slow } \\
\text { Tempo }\end{array}$ \\
\hline & & $43-47$ & Più mosso $\mathrm{q}=40$ & $\begin{array}{l}\text { More Movement or } \\
\text { Faster }\end{array}$ \\
\hline & & $48-49$ & Largo $\mathrm{q}=44$ & $\begin{array}{l}\text { Broad, Very Slow and } \\
\text { Dignified }\end{array}$ \\
\hline & & $50-51$ & Poco accel. al & $\begin{array}{l}\text { Slowly Accelerate to } \\
\text { Next Tempo Marking }\end{array}$ \\
\hline & & $52-53$ & Lento $\mathrm{q}=52$ & Slow \\
\hline & & $54-55$ & Accel. & Accelerate \\
\hline & & 56 & A Tempo $\mathrm{q}=52$ & $\begin{array}{l}\text { Return to Previous Set } \\
\text { Tempo }\end{array}$ \\
\hline Segment III & $\begin{array}{l}\text { Trecena (13-day } \\
\text { period); } 1 \text {-Malinalli } \\
\text { (grass) }\end{array}$ & $57-60$ & $q=52$ & \\
\hline
\end{tabular}




\begin{tabular}{|c|c|c|c|c|}
\hline Segments & $\begin{array}{l}\text { Related Aztec } \\
\text { Name }\end{array}$ & $\begin{array}{c}\text { Measure } \\
\text { Number/s }\end{array}$ & Tempo Markings & $\begin{array}{l}\text { Indication } \\
\text { Definition }\end{array}$ \\
\hline & & $61-69$ & Larghetto $\mathrm{q}=60$ & Rather Broadly \\
\hline & & 70 & Molto accel & Much Acceleration \\
\hline & & $71-72$ & Meno Mosso $q=52$ & Slower \\
\hline & & 73 & Largo $q=44$ & $\begin{array}{l}\text { Broad, Very Slow and } \\
\text { Dignified }\end{array}$ \\
\hline & & 74 & Strascinando e $=40$ & $\begin{array}{l}\text { Getting Gradually } \\
\text { Slower }\end{array}$ \\
\hline & & $75-86$ & Lento $\mathrm{q}=52$ & Slow \\
\hline & & $87-104$ & Moderato $\mathrm{q}=90$ & Moderate Speed \\
\hline \multirow[t]{7}{*}{ Segment IV } & $\begin{array}{l}\text { Xiuhpohualli (365- } \\
\text { day calendar); } 14 \text { - } \\
\text { Tepeilhuitl (feast of } \\
\text { the mountain) }\end{array}$ & $105-109$ & $\mathrm{q} .=52$ & \\
\hline & & $110-111$ & Larghetto $\mathrm{q}=60$ & Rather Broadly \\
\hline & & $112-122$ & Largo $q=44$ & $\begin{array}{l}\text { Broad, Very Slow and } \\
\text { Dignified }\end{array}$ \\
\hline & & $123-155$ & $q=60$ & \\
\hline & & $156-175$ & Più mosso $\mathrm{q}=40$ & Faster \\
\hline & & $176-177$ & Meno Mosso e $=60$ & Slower \\
\hline & & 178 & Strascinando e $=40$ & $\begin{array}{l}\text { Getting Gradually } \\
\text { Slower }\end{array}$ \\
\hline \multirow[t]{3}{*}{ Segment V } & $\begin{array}{l}\text { Yoalecuhtli (Lord of } \\
\text { the Night) }\end{array}$ & $179-180$ & $\begin{array}{l}\text { Larghissimo } q=40 \\
\text { bpm or slower }\end{array}$ & $\begin{array}{l}\text { Extremely Slow } \\
\text { Tempo }\end{array}$ \\
\hline & & $181-190$ & Larghetto $\mathrm{q}=60$ & Rather Broadly \\
\hline & & $191-197$ & Grave $\mathrm{q}=40$ & Very Slow and Solemn \\
\hline
\end{tabular}




\begin{tabular}{|l|l|l|l|l|}
\hline Segments & $\begin{array}{c}\text { Related Aztec } \\
\text { Name }\end{array}$ & $\begin{array}{c}\text { Measure } \\
\text { Number/s }\end{array}$ & Tempo Markings & \multicolumn{1}{|c|}{$\begin{array}{c}\text { Indication } \\
\text { Definition }\end{array}$} \\
\hline & & $198-200$ & Lento q $=52$ & Slow \\
\hline & & $201-202$ & Grave q $=40$ & Very Slow and Solemn \\
\hline & & $203-306$ & Lento q $=52$ & Slow \\
\hline
\end{tabular}




\section{APPENDIX - B}

\section{Bilateral Symmetry Assignment Table}

\begin{tabular}{|c|c|c|c|c|}
\hline Segment & $\begin{array}{l}\text { Measure } \\
\text { Number/s }\end{array}$ & Instrument & pitches & $\begin{array}{l}\text { Orchestra } \\
\text { Section }\end{array}$ \\
\hline \multirow[t]{9}{*}{ Segment II } & $46-47$ & Soprano / Bass Voice & $\mathrm{D}, \mathrm{G}$ & Choir \\
\hline & $46-$ & Alto / Tenor & A & Choir \\
\hline & $48-55$ & Soprano / Alto Voice & $\begin{array}{l}\mathrm{D}, \mathrm{Eb}, \mathrm{Bb}, \mathrm{A}, \\
\mathrm{F} \#, \mathrm{G}\end{array}$ & Choir \\
\hline & $48-56$ & Tenor / Bass & $\begin{array}{l}\mathrm{Eb}, \mathrm{G}, \mathrm{A}, \mathrm{Bb} \\
\mathrm{F}, \mathrm{D}\end{array}$ & Choir \\
\hline & $50-56$ & Oboe / Contrabassoon & $\mathrm{A}, \mathrm{Bb}, \mathrm{Eb}$ & Wind \\
\hline & $50-56$ & English Horn / Bassoon & $\mathrm{A}, \mathrm{Bb}, \mathrm{Eb}$ & Wind \\
\hline & $50-56$ & Clarinet / Bass Clarinet & $\mathrm{A}, \mathrm{Bb}, \mathrm{Eb}$ & Wind \\
\hline & $49-56$ & French Horn / Tuba & $\mathrm{F} \#, \mathrm{G}$ & Brass \\
\hline & $50-56$ & Trumpet / Trombones & $\mathrm{F} \#, \mathrm{G}$ & Brass \\
\hline \multirow[t]{12}{*}{ Segment III } & 73 & Piccolo / Tuba & $\mathrm{Eb}$ & Wind / Brass \\
\hline & 73 & Flute / Trombone & $\mathrm{Db}, \mathrm{B}$ & Wind / Brass \\
\hline & 73 & Oboe / Trumpet & $\mathrm{Gb}, \mathrm{Db}$ & Wind / Brass \\
\hline & 73 & English Horn / French Horn & $\mathrm{Ab}$ & Wind / Brass \\
\hline & 73 & Clarinet / Contrabassoon & $\mathrm{Db}$ & Wind / Brass \\
\hline & 73 & Bass Clarinet / Bassoon & $\mathrm{B}$ & Wind / Brass \\
\hline & $79-87$ & $\begin{array}{l}\text { Soprano Voice / Piccolo / Oboe / } \\
\text { Violin I }\end{array}$ & $\begin{array}{l}\mathrm{Ab}, \mathrm{Gb}, \mathrm{Eb}, \mathrm{Db} \\
\mathrm{B},\end{array}$ & $\begin{array}{l}\text { Wind / Choir / } \\
\text { String }\end{array}$ \\
\hline & $79-87$ & $\begin{array}{l}\text { Alto Voice / Flute / English Horn / } \\
\text { Violin II }\end{array}$ & $\begin{array}{l}\mathrm{Db}, \mathrm{B}, \mathrm{Ab}, \mathrm{Gb} \\
\mathrm{Eb},\end{array}$ & $\begin{array}{l}\text { Wind / Choir / } \\
\text { String }\end{array}$ \\
\hline & $79-87$ & $\begin{array}{l}\text { Tenor Voice / Clarinet / Bassoon / } \\
\text { Viola }\end{array}$ & $\begin{array}{l}\mathrm{Eb}, \mathrm{Gb}, \mathrm{Ab}, \mathrm{B} \\
\mathrm{Db}\end{array}$ & $\begin{array}{l}\text { Wind / Choir / } \\
\text { String }\end{array}$ \\
\hline & $79-87$ & $\begin{array}{l}\text { Bass Voice / Contrabassoon / Bass } \\
\text { Clarinet / Cello / Contrabass }\end{array}$ & $\mathrm{Gb}, \mathrm{Ab}, \mathrm{B}, \mathrm{Eb}$ & $\begin{array}{l}\text { Wind / Choir / } \\
\text { String }\end{array}$ \\
\hline & 88 & $\begin{array}{l}\text { Soprano Voice / Piccolo / Oboe / } \\
\text { French Horn / Violin I }\end{array}$ & $\mathrm{Gb} \mathrm{Eb}, \mathrm{Db}, \mathrm{B}$ & $\begin{array}{l}\text { Wind / Brass / } \\
\text { Choir / String }\end{array}$ \\
\hline & 88 & $\begin{array}{l}\text { Alto Voice / Flute / English Horn / } \\
\text { Trumpet / Violin II }\end{array}$ & $\begin{array}{l}\mathrm{B}, \mathrm{Ab}, \mathrm{Gb}, \mathrm{Eb} \\
\mathrm{Db}\end{array}$ & $\begin{array}{l}\text { Wind / Brass / } \\
\text { Choir / String }\end{array}$ \\
\hline
\end{tabular}




\begin{tabular}{|c|c|c|c|c|}
\hline Segment & $\begin{array}{l}\text { Measure } \\
\text { Number/s }\end{array}$ & Instrument & pitches & $\begin{array}{l}\text { Orchestra } \\
\text { Section }\end{array}$ \\
\hline & $88-89$ & $\begin{array}{l}\text { Tenor Voice / Clarinet / Bassoon / } \\
\text { Viola }\end{array}$ & $\begin{array}{l}\mathrm{Eb}, \mathrm{Gb}, \mathrm{Ab}, \mathrm{B} \\
\mathrm{Db}\end{array}$ & $\begin{array}{l}\text { Wind / Choir / } \\
\text { String }\end{array}$ \\
\hline & 88 & Bass Voice / Tuba & $\mathrm{Gb}$ & Choir / Brass \\
\hline & $93-103$ & $\begin{array}{l}\text { Soprano / Tenor Voice / Violin I / } \\
\text { Viola }\end{array}$ & $\begin{array}{l}\mathrm{Gb} \mathrm{Eb}, \mathrm{Db}, \mathrm{Ab}, \\
\mathrm{B}\end{array}$ & Choir / String \\
\hline & $94-103$ & $\begin{array}{l}\text { Bass / Alto Voice / Violin II / } \\
\text { Cello / Contrabass }\end{array}$ & $\begin{array}{l}\mathrm{B}, \mathrm{Db}, \mathrm{Eb}, \mathrm{Ab} \\
\mathrm{Gb}\end{array}$ & Choir / String \\
\hline \multirow[t]{19}{*}{ Segment IV } & $115-117$ & French Horn / Tuba & A & Brass \\
\hline & 117 & English Horn / Bassoon & $\mathrm{Bb}$ & Wind \\
\hline & 117 & Clarinet / Bass Clarinet & G & Wind \\
\hline & $118-134$ & Oboe / Contrabassoon & $\mathrm{D}$ & Wind \\
\hline & $118-134$ & English Horn / Bassoon & $\mathrm{Bb}$ & Wind \\
\hline & $118-134$ & Clarinet / Bass Clarinet & G & Wind \\
\hline & $118-134$ & French Horn / Tuba & $\mathrm{Eb}$ & Brass \\
\hline & $118-134$ & Trumpet / Trombones & $\mathrm{G}, \mathrm{F} \#$ & Brass \\
\hline & $132-137$ & Violin I / Contrabass & $\mathrm{D}$ & String \\
\hline & $132-137$ & Violin II / Cello & $\mathrm{Bb}$ & String \\
\hline & $131-137$ & Viola & $\mathrm{G}, \mathrm{A}$ & String \\
\hline & $138-147$ & Piccolo / Xylophone & $\mathrm{D}, \mathrm{F} \#, \mathrm{Bb}, \mathrm{A}, \mathrm{G}$ & $\begin{array}{l}\text { Wind / } \\
\text { Percussion }\end{array}$ \\
\hline & $138-147$ & Flute / Xylophone & $\begin{array}{l}\mathrm{Eb}, \mathrm{A}, \mathrm{G}, \mathrm{D}, \mathrm{Bb} \\
\mathrm{F} \#\end{array}$ & $\begin{array}{l}\text { Wind / } \\
\text { Percussion }\end{array}$ \\
\hline & 164 & Violin I divsi 1 / Violin II divisi 1 & $\mathrm{Bb}$ & String \\
\hline & 164 & Violin I divsi 2 / Violin II divisi 2 & $\mathrm{D}$ & String \\
\hline & 164 & Viola I / Contrabass & $\mathrm{G}, \mathrm{Eb}, \mathrm{A}, \mathrm{Bb}$ & String \\
\hline & $165-167$ & $\begin{array}{l}\text { Bass Clarinet / Bass Voice / } \\
\text { Contrabass }\end{array}$ & $\mathrm{D}$ & $\begin{array}{l}\text { Wind / Choir / } \\
\text { String }\end{array}$ \\
\hline & $165-167$ & $\begin{array}{l}\text { Tenor Voice / Clarinet / Bassoon / } \\
\text { Trombone }\end{array}$ & $\mathrm{D}$ & $\begin{array}{l}\text { Wind / Brass / } \\
\text { Choir }\end{array}$ \\
\hline & 166 & $\begin{array}{l}\text { Flute / English Horn / Trumpet / } \\
\text { Alto Voice }\end{array}$ & A & $\begin{array}{l}\text { Wind / Brass / } \\
\text { Choir }\end{array}$ \\
\hline
\end{tabular}




\begin{tabular}{|c|c|c|c|c|}
\hline Segment & $\begin{array}{l}\text { Measure } \\
\text { Number/s }\end{array}$ & Instrument & pitches & $\begin{array}{l}\text { Orchestra } \\
\text { Section }\end{array}$ \\
\hline & $166-167$ & $\begin{array}{l}\text { Piccolo / Oboe / French Horn / } \\
\text { Soprano Voice }\end{array}$ & A & $\begin{array}{l}\text { Wind / Brass / } \\
\text { Choir }\end{array}$ \\
\hline & $167-170$ & $\begin{array}{l}\text { Bass Clarinet / Contra Bassoon / } \\
\text { Tuba / Contrabass }\end{array}$ & $\mathrm{D}$ & $\begin{array}{l}\text { Wind / Brass / } \\
\text { String }\end{array}$ \\
\hline & $167-170$ & Clarinet / Trombone / Cello & F\# & Wind / Brass \\
\hline & $167-170$ & Bassoon / Trumpet / Viola & $\mathrm{F} \#, \mathrm{C}$ & Wind / Brass \\
\hline & $167-170$ & $\begin{array}{l}\text { Flute / English Horn / French } \\
\text { Horn / Violin II }\end{array}$ & A, D & $\begin{array}{l}\text { Wind / Brass / } \\
\text { String }\end{array}$ \\
\hline & $167-171$ & Piccolo / Oboe / Violin I & A, D & $\begin{array}{l}\text { Wind / Brass / } \\
\text { String }\end{array}$ \\
\hline & $171-174$ & $\begin{array}{l}\text { Soprano / Alto Voice / Celesta } \\
\text { Right Hand / Piano Right Hand }\end{array}$ & $\begin{array}{l}\mathrm{Eb}, \mathrm{D}, \mathrm{Bb}, \mathrm{A}, \mathrm{G}, \\
\mathrm{F} \#\end{array}$ & $\begin{array}{l}\text { Choir / } \\
\text { Keyboard }\end{array}$ \\
\hline & $171-174$ & $\begin{array}{l}\text { Tenor / Bass Voice / Celesta Left } \\
\text { Hand }\end{array}$ & $\begin{array}{l}\mathrm{D}, \mathrm{A}, \mathrm{G}, \mathrm{F} \#, \mathrm{~Eb} \\
\mathrm{Bb}\end{array}$ & $\begin{array}{l}\text { Choir / } \\
\text { Keyboard }\end{array}$ \\
\hline & $171-174$ & Bass Voice / Piano Left Hand & $\begin{array}{l}\mathrm{G}, \mathrm{F} \#, \mathrm{D}, \mathrm{Bb}, \mathrm{A} \\
\mathrm{Eb}\end{array}$ & $\begin{array}{l}\text { Choir / } \\
\text { Keyboard }\end{array}$ \\
\hline & $172-174$ & Flute / Violin II & $\mathrm{F} \#$ & Wind / String \\
\hline & $173-174$ & Piccolo / Violin I & $\mathrm{F} \#$ & Wind / String \\
\hline & $172-178$ & Oboe / Contrabassoon & $\mathrm{D}$ & Wind \\
\hline & $172-178$ & English Horn / Bassoon & $\mathrm{Bb}$ & Wind \\
\hline & $172-178$ & Clarinet / Bass Clarinet & $\mathrm{Eb}$ & Wind \\
\hline & $172-178$ & French Horn / Tuba & A & Brass \\
\hline & $172-178$ & Trumpet / Trombones & $\mathrm{G}, \mathrm{F} \#$ & Brass \\
\hline
\end{tabular}




\section{APPENDIX - C}

\section{Moving May-SHEE-Ka Scale Structure A}

Descending May-SHEE-Ka Scale, Score Page 39

\begin{tabular}{|l|l|l|l|l|l|l|}
\hline Measures & 172 & 172 & 173 & 173 & 174 & 174 \\
\hline Soprano Voice & Eb & D & Bb & A & G & F\# \\
\hline & & & & & & \\
\hline Alto Voice & A & Bb & F\# & Eb & F\# & D \\
\hline & & & & & & \\
\hline Tenor Voice & D & A & G & F\# & Eb & F\# \\
\hline & Bb & G & Eb & D & Bb & D \\
\hline & & & & & & \\
\hline Bass Voice & G & F\# & D & Bb & G & Bb \\
\hline & F\# & D & A & G & F\# & G \\
\hline
\end{tabular}


Moving May-SHEE-Ka Scale

Structure B

Descending May-SHEE-Ka Scale, Score Page 40

\begin{tabular}{|c|l|l|l|l|l|l|l|l|}
\hline Measures & 175 & 175 & 175 & 176 & 176 & 177 & 177 & 178 \\
\hline Soprano Voice & F\# & A & Bb & D & Eb & F\# & G & A \\
\hline & & & & & & & & \\
\hline Alto Voice & G & Eb & F\# & Bb & A & Bb & Eb & F\# \\
\hline Measures & 175 & 175 & 176 & 176 & 177 & 177 & 178 & \\
\hline Tenor Voice & G & A & D & Eb & F\# & G & G & \\
\hline & Eb & G & Bb & G & Bb & D & Eb & \\
\hline & & & & & & & & \\
\hline Bass Voice & D & F\# & G & A & A & Bb & D & \\
\hline & A & D & F\# & D & D & Eb & F\# & \\
\hline
\end{tabular}




\section{APPENDIX - D \\ Bilateral Symmetry Grouping One}

Measures 48 - 56

Choir

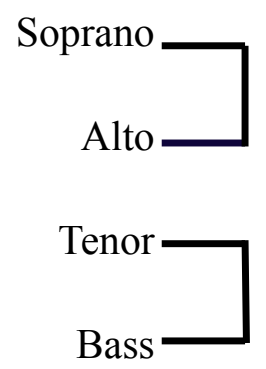

Brass

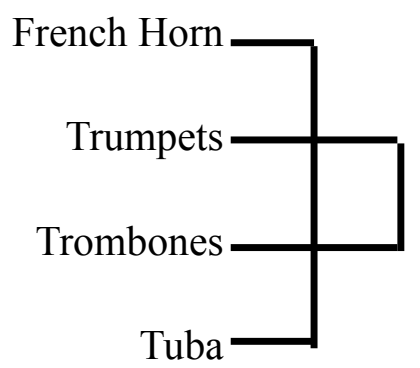

Wood Winds

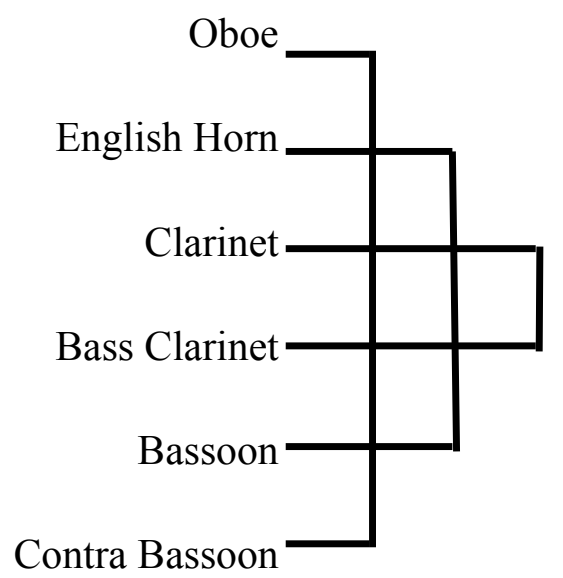




\section{Bilateral Symmetry Grouping Two}

Measures 71 - 74

Mexica Pentatonic Scale

\section{Choir}

Wood Winds
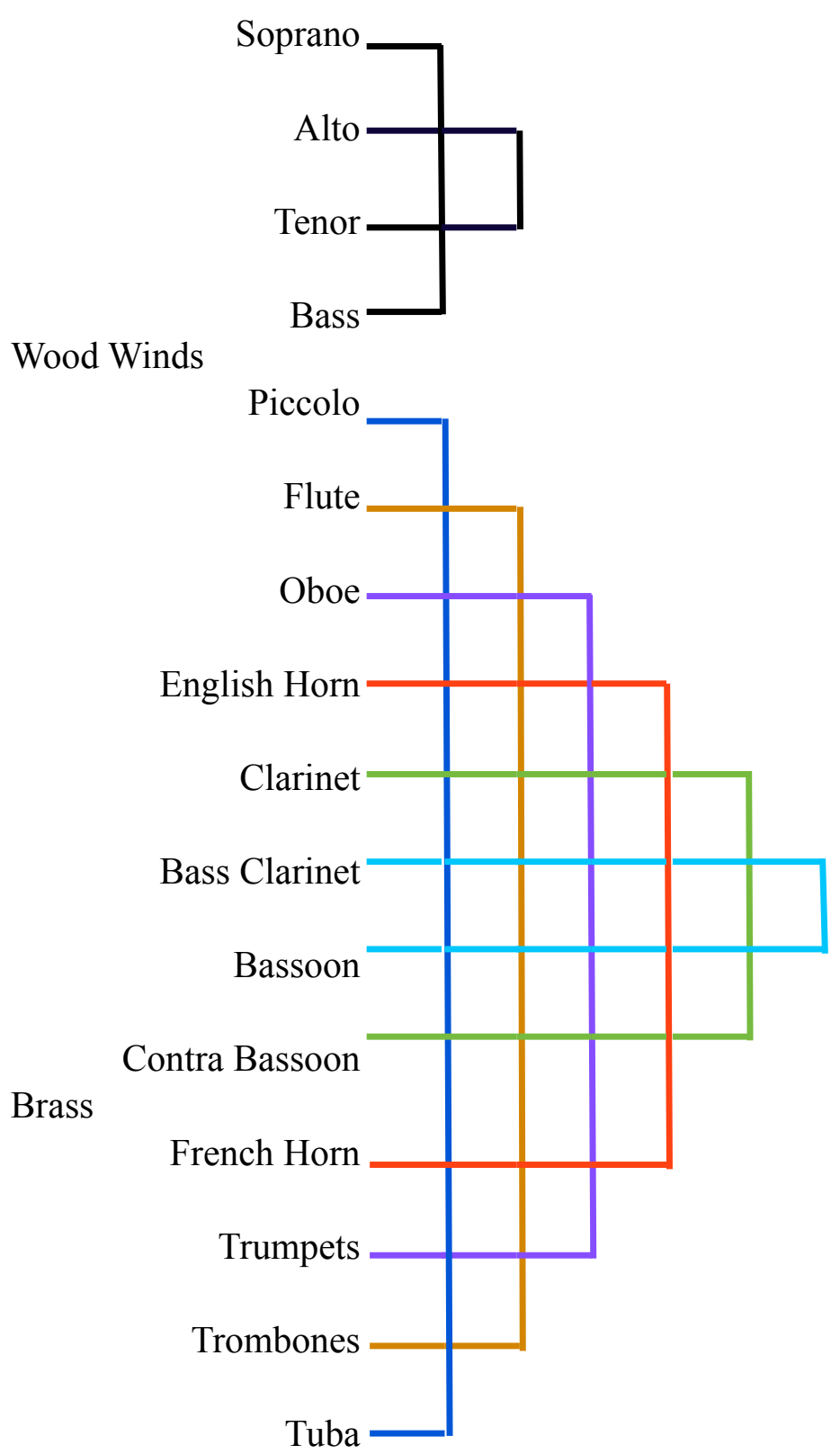


\section{Bilateral Symmetry Grouping 3}

Measures 79 - 90, \& 95 - 103

Mexica Pentatonic Scale

Choir

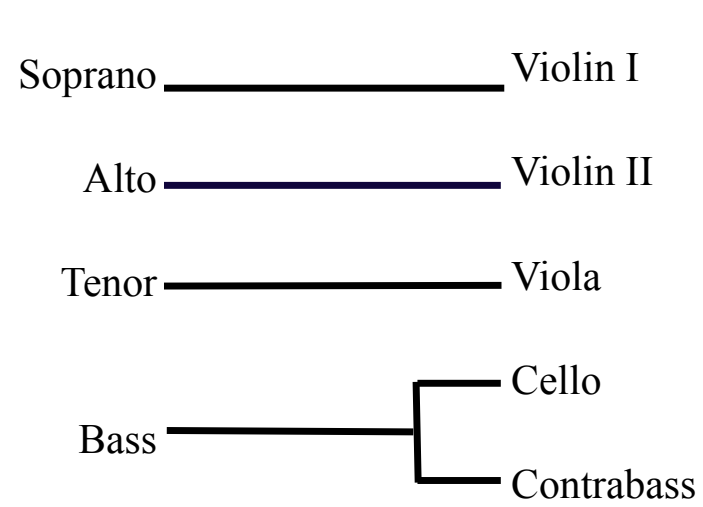

Strings

Score Pages 19 - 20, \& 24

Wood Winds

Mexica Pentatonic Scale

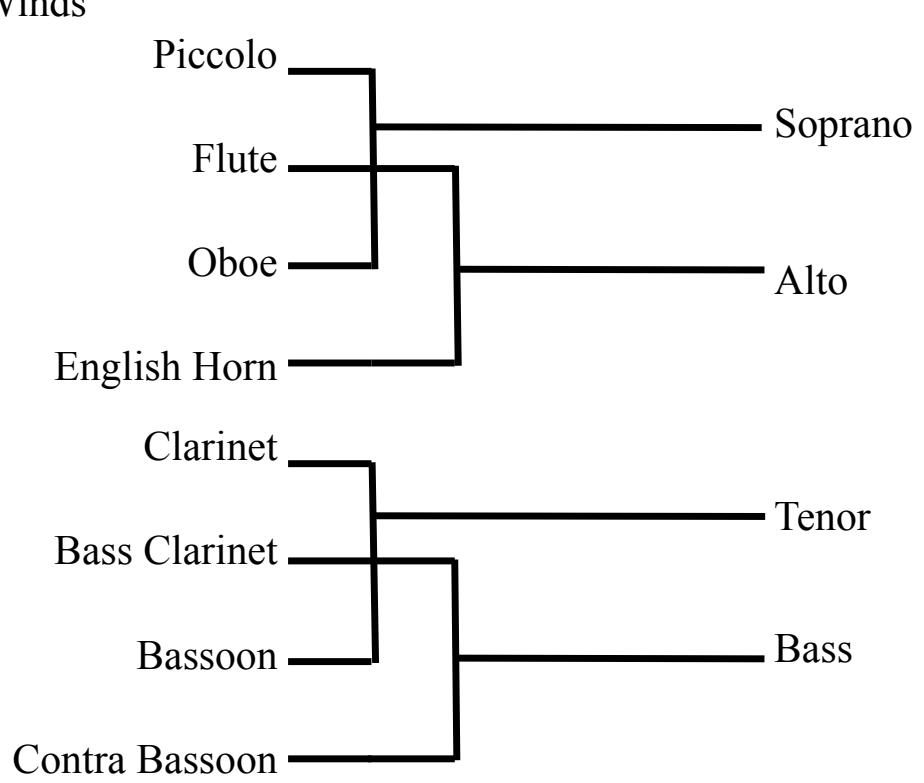

Choir

Score Pages 20, 22, 23, \& 24

Mexica Pentatonic Scale

Choir

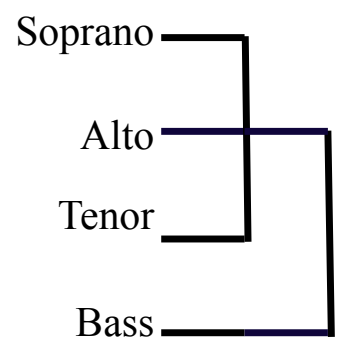




\section{Bilateral Symmetry Grouping 3 Continued}

Measures 95 - 104

Mexica Pentatonic Scale

Percussion
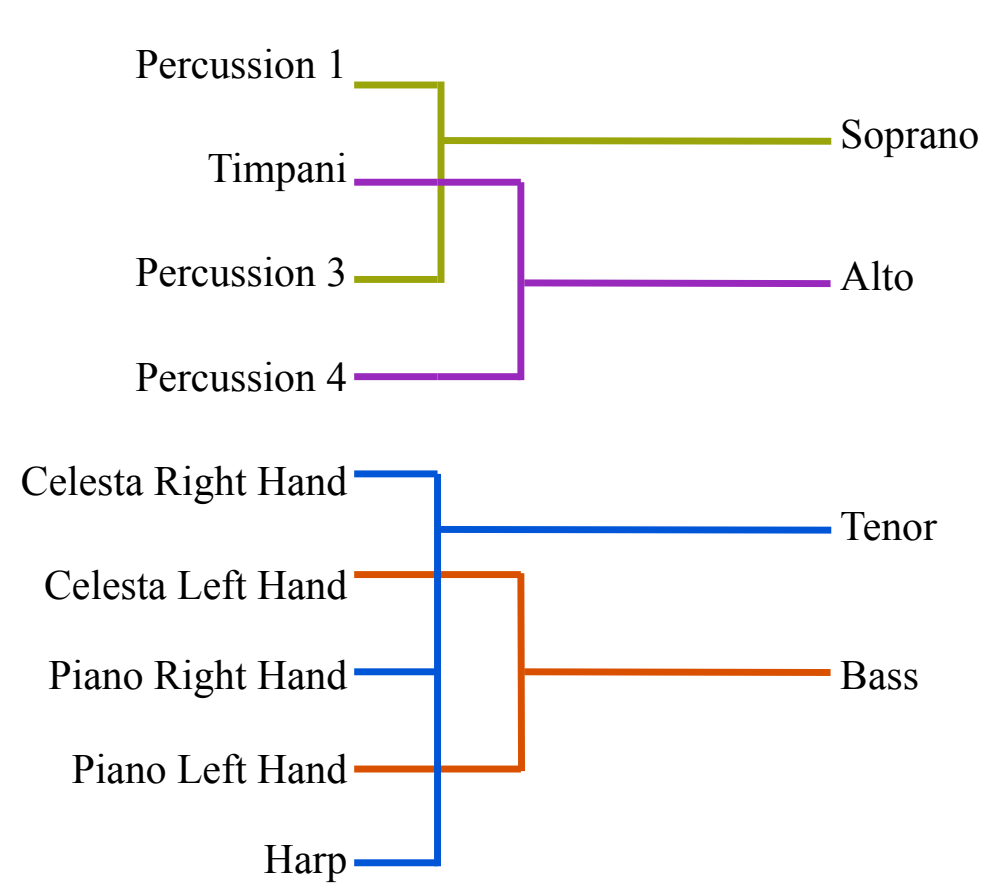

Choir

Measures 99 - 103

Mexica Pentatonic Scale

Choir

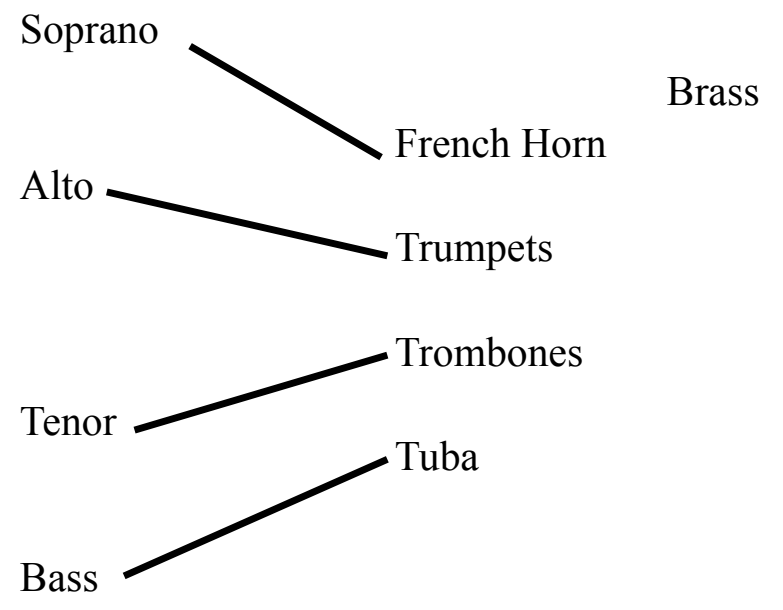




\section{Bilateral Symmetry Grouping 4 \\ Measures 112 - 129 \\ May-SHEE-Ka Synthetic Scale}

Wood Winds

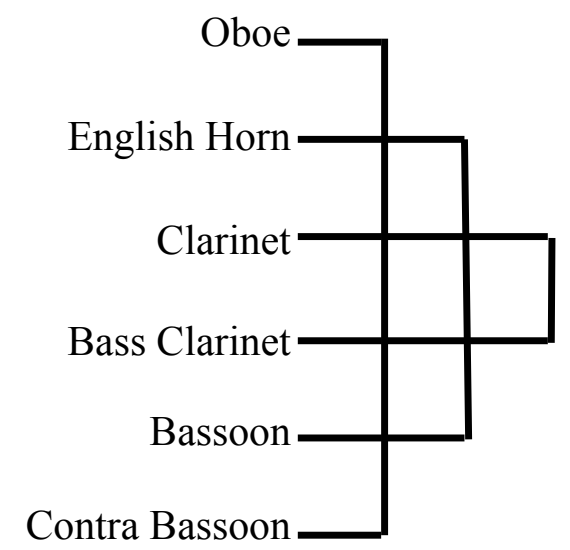

Brass

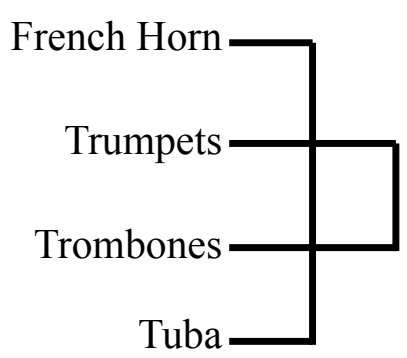

Score Pages 28, \& 29

May-SHEE-Ka Synthetic Scale

Choir

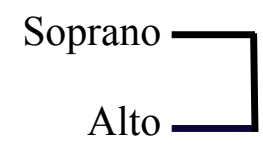

Score Pages 30, \& 31

Tenor
Bass

Strings

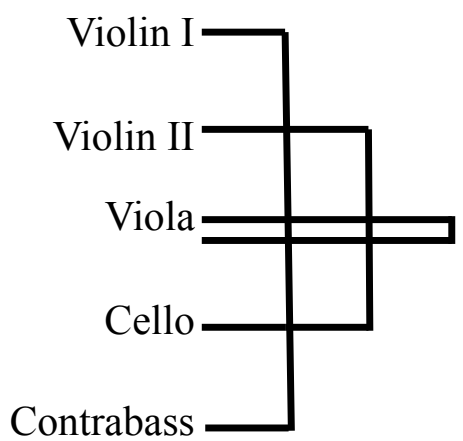




\section{Bilateral Symmetry Grouping 5 \\ Measures 135 - 149 \\ May-SHEE-Ka Synthetic Scale}

Wood Winds

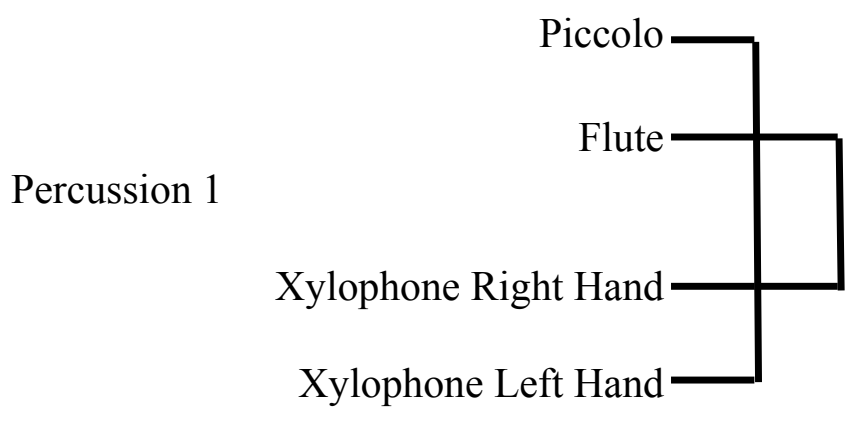

\section{Bilateral Symmetry Grouping 6}

Measures 163 - 166

May-SHEE-Ka Synthetic Scale

Wood Winds

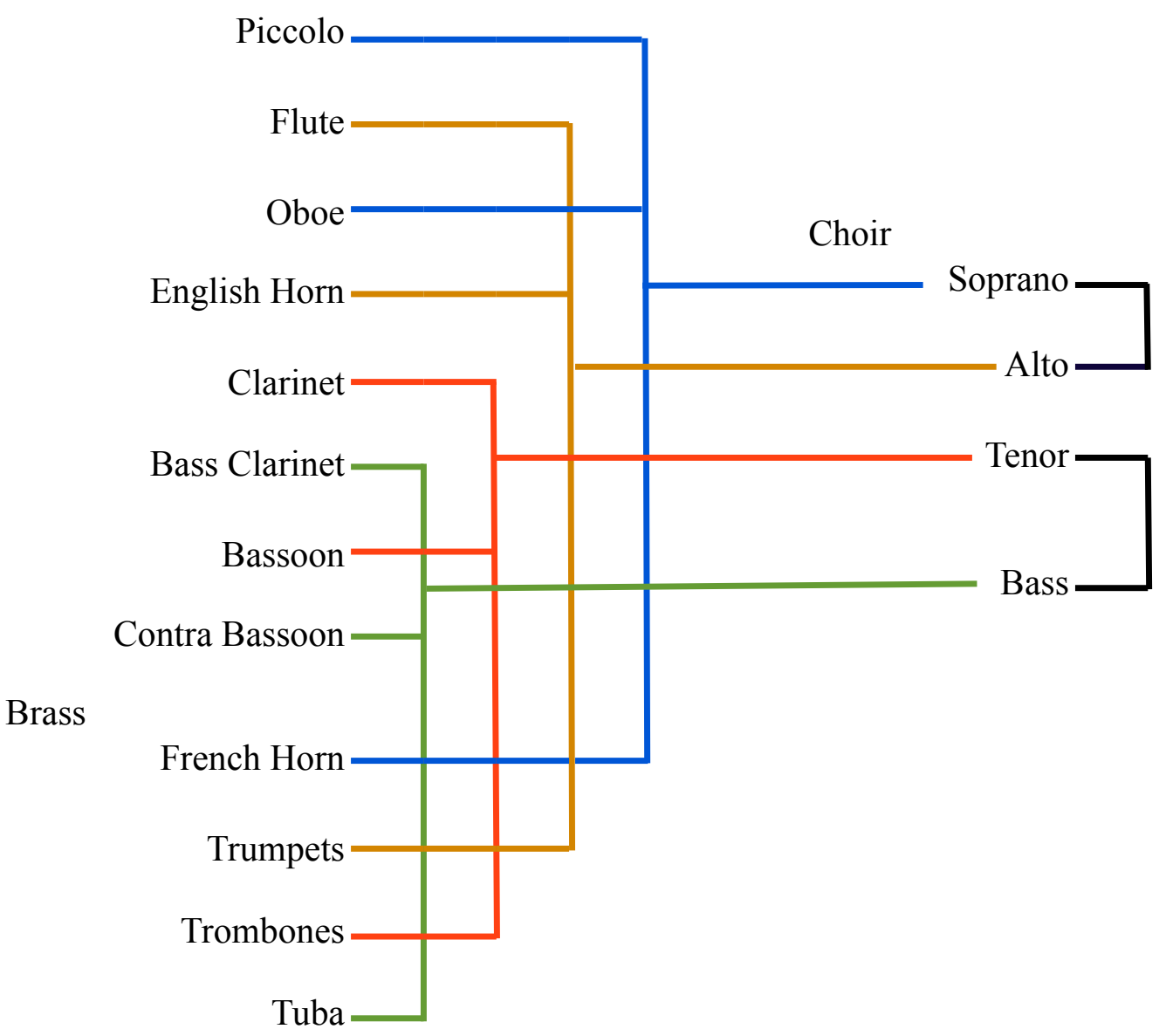




\section{Bilateral Symmetry Grouping 6 Continued \\ Measures 163 - 166 \\ May-SHEE-Ka Synthetic Scale}

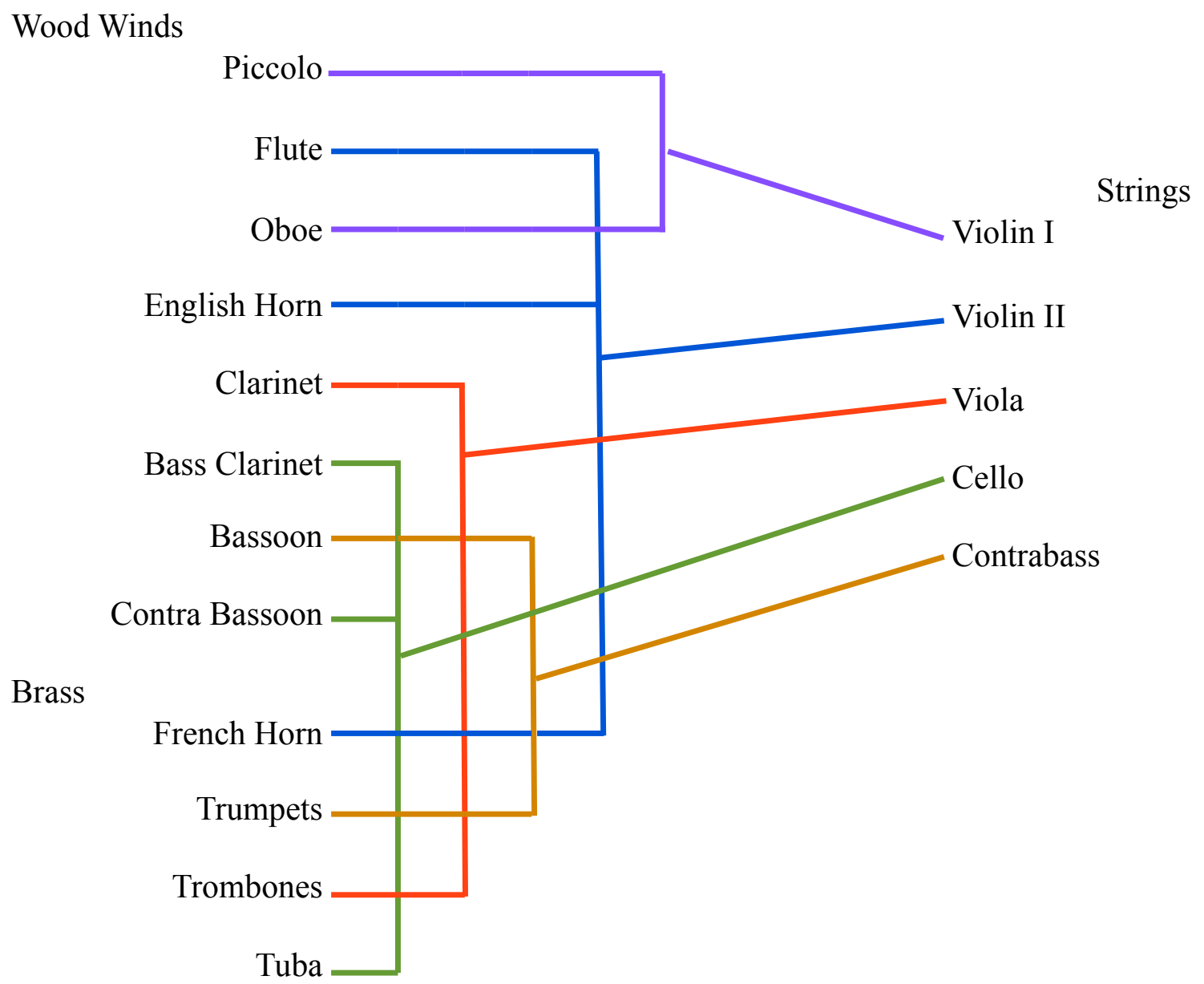




\section{Bilateral Symmetry Grouping 7 \\ Measures 171 - 174 \\ May-SHEE-Ka Synthetic Scale}

Wood Winds

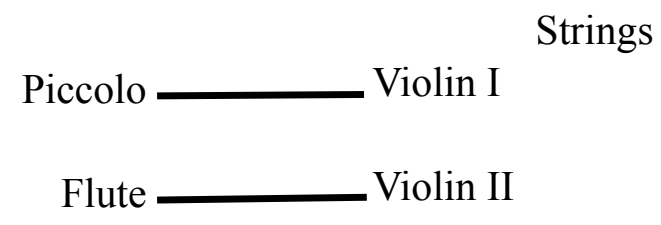

Wood Winds

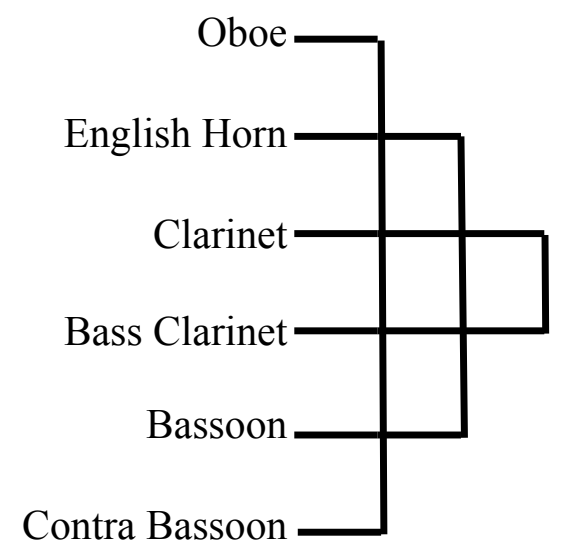

Brass

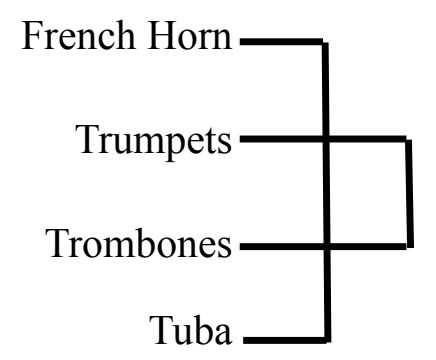

